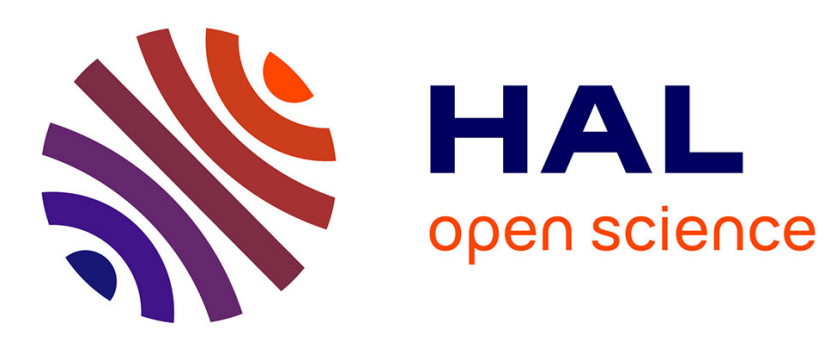

\title{
The role of intra-articular hyaluronan (Sinovial) in the treatment of osteoarthritis
}

\author{
Antonio Gigante, Leonardo Callegari
}

\section{To cite this version:}

Antonio Gigante, Leonardo Callegari. The role of intra-articular hyaluronan (Sinovial) in the treatment of osteoarthritis. Rheumatology International, 2010, 31 (4), pp.427-444. 10.1007/s00296-0101660-6 . hal-00645366

\section{HAL Id: hal-00645366 https://hal.science/hal-00645366}

Submitted on 28 Nov 2011

HAL is a multi-disciplinary open access archive for the deposit and dissemination of scientific research documents, whether they are published or not. The documents may come from teaching and research institutions in France or abroad, or from public or private research centers.
L'archive ouverte pluridisciplinaire HAL, est destinée au dépôt et à la diffusion de documents scientifiques de niveau recherche, publiés ou non, émanant des établissements d'enseignement et de recherche français ou étrangers, des laboratoires publics ou privés. 


\title{
The Role of Intra-articular Hyaluronan (Sinovial $^{\circledR}$ ) in the Treatment of Osteoarthritis
}

\author{
Professor Antonio Gigante $^{a^{*}}$, Dr. Leonardo Callegari ${ }^{b}$ \\ * Corresponding author
}

\begin{abstract}
Affiliations
${ }^{a}$ Università Politecnica delle Marche, Dipartimento di Patologia Molecolare e Terapie Innovative, Sezione Clinica Ortopedica, Via Tronto 10, 60020 Ancona, Italia

${ }^{\mathrm{b}}$ Cattedra di Radiologia dell'Università dell'Insubria, Ospedale di Circolo e Fondazione Macchi, Viale Borri 57, 21100 Varese, Italia
\end{abstract}

\section{Corresponding author}

Professor Antonio Gigante

Università Politecnica delle Marche

Dipartimento di Patologia Molecolare e Terapie Innovative

Sezione Clinica Ortopedica

Via Tronto, 10

60020 Ancona, Italia

Phone: $+39.0712206069-3389658099$

Fax: +39.0712206066

Email: a.gigante@univpm.it; Michele.fasola@ibsa.ch

Running Title: Sinovial® in osteoarthritis 


\begin{abstract}
Osteoarthritis (OA) leads to significant pain and disability. For pain relief, a tailored approach using non-pharmacological and pharmacological therapies is recommended. If adequate symptom relief is not achieved with acetaminophen, other pharmacological options include nonsteroidal anti-inflammatory drugs (NSAIDs), topical analgesics, intra-articular corticosteroids, and intra-articular hyaluronic acid (HA) viscosupplementation. Most of these therapies generally do not improve functional ability or quality of life, or are associated with tolerability concerns. In OA patients, concentration and molecular weight (MW) of HA are reduced, diminishing elastoviscosity of the synovial fluid, joint lubrication and shock absorbancy, and possibly anti-inflammatory, analgesic and chondroprotective effects. In knee OA, viscosupplementation with 3-5 weekly intra-articular HA injections diminishes pain and improves disability, generally within one week and for up to 3-6 months, and is well tolerated. HAs have comparable efficacy as NSAIDs, with less gastrointestinal adverse events, and compared with intra-articular corticosteroids, benefits last generally longer. High MW hylans provide comparable benefits versus HA, albeit with an increased risk of immunogenic adverse events. In mild-tomoderate hip OA, intra-articular injection of HA moderately improved pain and function, generally for up to 3 months with no serious adverse events. Efficacy in other joints is being evaluated.

Viscosupplementation with intra-articular Sinovial ${ }^{\circledR} *$ injections (an HA of lowmedium MW) relieves pain and improves function in OA of the knee, and other joints including the carpometacarpal joint of the thumb and the shoulder. HA viscosupplementation, including use of Sinovial ${ }^{\circledR}$, is a valuable treatment approach for OA patients, if other therapies are contraindicated or have failed.
\end{abstract}

Key words: osteoarthritis, hyaluronic acid, viscosupplementation, viscoinduction *Other tradenames: Yaral ${ }^{\circledR}$, Intragel ${ }^{\circledR}$ 


\section{Introduction}

Osteoarthritis (OA) is the most common form of arthritis [1] and is responsible for considerable clinical and economic burden as a result of reduced quality of life (due to pain, disability, loss of mobility and independence), increased use of health care resources, and lost of productivity. Although OA is essentially a broad clinical syndrome, it is characterised by the progressive loss of articular cartilage and chondrocytes within the synovial joints that manifests as chronic joint pain and functional limitation as a result of joint stiffness and progressive loss in the range of joint motion.

It is reported to be the most common cause of long-term disability after chronic heart disease, with an estimated prevalence in adults of up to $16 \%$ in women and $25 \%$ in men.[2] Moreover, it is one of the most common causes of disability worldwide;[1] $80 \%$ of patients with OA have some degree of movement limitation and $25 \%$ cannot perform activities of daily life.[3]

The prevalence of OA increases with age; for those aged between 55-74 years, the estimated prevalence of OA of the hand is $70 \%$, foot $40 \%$, knee $10 \%$ and hip 3\%.[2] Interestingly, below the age of 45 , more men are affected than women, while over the age of 45 , more women are affected than men.[2] It is not surprising then that demographic changes including longer life expectancy, higher levels of obesity and lower levels of physical fitness are increasing the burden and demand for OA-related health resources.[2]

Any synovial joint may be affected by OA, but it is mainly seen in the weight bearing joints found in the knees, hands and hips.[1] Treatment options are primarily aimed at relieving the pain stemming from OA, yet many patients do not respond to management strategies involving non-pharmacological interventions, or are not able to tolerate analgesic/anti-inflammatory therapy due to tolerability concerns, especially in the elderly.[4, 5]

Among the different treatment modalities available for the management of OA, viscosupplementation with hyaluronic acid (HA) is widely accepted in the clinical practice. 
The objectives of this paper are to examine the rationale and the efficacy of intraarticular HA products (in general) and of Sinovial ${ }^{\circledR}$ (also known as Yaral $^{\circledR} /$ Intragel $^{\circledR}$ ), in particular, in the management of OA. References included in this review were selected by non-systematic literature searches of PubMed and treatment guidelines.

\section{Pathology of OA}

$\mathrm{OA}$ is recognised as a metabolically active, dynamic process of degradation and synthesis involving all tissues of the affected joint including cartilage, bone, synovium, ligaments and muscle.[1] The pathological changes result from failure of the repair process of the synovial joints that is activated by joint damage, and includes loss of chondrocytes and cartilage matrix, and bone remodelling, leading to biomechanical joint failure.

While the aetiology of OA is not completely understood, a number of risk factors are known to contribute including genetic, constitutional (obesity, age, gender, high bone density) and biomechanical (injury, occupational or recreational joint trauma, muscle weakness).[1] Some of these risk factors are modifiable or avoidable, such as environmental or lifestyle factors including obesity, muscle weakness and occupational or recreational joint trauma. Importantly, some may contribute to OA development (high bone density) while others are considered to be risk factors for disease progression and poor clinical outcome (low bone density).

OA-related pain, the earliest and most consistent symptom of the disease is generally caused by the strain that irregular cartilage and the loss of joint structure puts on the adjacent ligaments, muscles, and connective tissues.[6] The demonstration of pain receptors in tissues around joints (but not in cartilage, menisci, and the synovial cavity) suggests an involvement in triggering pain and the release of inflammatory mediators (e.g., substance P).[6]

\section{Management Strategies}

To date, there is no a definitive cure for OA, hence the goals of treatment are focused on the relief of pain, maintenance and/or improvement in joint mobility, and in limiting functional impairment that impacts on an individual's ability to perform activities of daily living (ADL). Both expert consensus and research evidence 
contribute to the EULAR recommendations for the management of knee[7] and hip[8] OA. The optimal management of OA of the knee requires a combination of nonpharmacological and pharmacological treatment modalities. Treatment should be tailored according to: knee risk factors (obesity, adverse mechanical factors, physical activity); general risk factors (age, comorbidity, polypharmacy); level of pain, intensity and disability; signs of inflammation (e.g., effusion); and the location and degree of any structural damage.[7]

Non-pharmacologic management strategies such as regular patient education, weight reduction, use of orthotics, exercise and mechanical supports, are advocated for patients with mild symptoms.[7] Among the available pharmacologic options for the treatment of pain associated with OA of the knee, oral acetaminophen (paracetamol) is the first line therapy, and if favourable, is the preferred long-term oral analgesic. For patients in whom these measures do not provide adequate symptom relief, subsequent treatment options include topical application of a non-steroidal antiinflammatory drug (NSAID) or capsaicin, and systemic NSAIDs. In patients with an increased gastrointestinal risk (e.g., the elderly, those with ulcers), non-selective NSAIDs and gastroprotective agents, or selective COX-2 inhibitors should be considered. Administration of chondroitin sulfate, glucosamine sulphate, avocadosoybean unsaponifiables (ASU), diacerin and hyaluronic acid, which mimic natural hyaluronan, have symptomatic effect and may also modify structure. Intra-articular administration of corticosteroids may be also considered, especially for flare of knee pain, accompanied by effusion. Failing conservative pharmacological options, surgical treatment may be considered, while alternative/complementary therapies e.g., acupuncture, have also been associated with benefits in OA.

\section{Rationale for the Use of Hyaluronan Derivatives}

\section{Function of Natural Hyaluronan}

Hyaluronan (also referred to as hyaluronic acid [HA] or sodium hyaluronate) is a highly viscous polysaccharide found in the extracellular matrix, particularly in soft connective tissues and is a major component of the synovial fluid and of cartilage.[9] Following synthesis in the joints by chondrocytes and synoviocytes, HA is released 
into the synovial space and accumulates on cartilage and ligament surfaces. Belonging to the family of glycosaminoglycans, the HA molecule is composed of 1000s of repeating disaccharide units ( $\mathrm{N}$-acetylglucosamine and glucuronic acid) to form a long polysaccharide chain of varying length with a high molecular weight (3-4 x $10^{6}$ Da) that when fully hydrated, occupies a large spherical domain. In addition to its elastic and viscous properties, this physical presence of HA supports its significant role in maintaining the rheological homeostasis of the synovial fluid in the joint, and also contributes to lubrication, shock absorption, elasticity, hydration and nutrition for the joint tissue.

The normal concentration of HA in the synovial fluid of the human knee is about 2.5$4.0 \mathrm{mg} / \mathrm{mL}$ (with an estimated total concentration of 4-8 mg/knee); however, in pathological conditions, both the concentration (estimated to be halved, 1-2 $\mathrm{mg} / \mathrm{ml}$ )[9] and molecular weight of HA are reduced resulting in synovial fluid of lower elasticity and viscosity, with a consequent impact on the joint.[10].

\section{Injection of Exogenous Hyaluronan Derivatives}

Intra-articular injections of HA (i.e., viscosupplementation) are approved worldwide for the treatment of pain associated with OA of the knee. The aim of HA treatment is to reduce pain and improve physical function by supplementing the viscosity and elasticity of synovial fluid which are reduced in OA.[7, 11] Most commercial preparations of HA have the same structure as endogenous HA, although high molecular weight products containing cross-linked HA molecules (hylans) have also been engineered (e.g., hylan G-F 20 has a MW of 6,000kDa) to achieve greater elastoviscosity and intra-articular dwell-time.[1]

The exact mechanism of action of injected HA is not well understood; however, it is believed that several mechanisms contribute to the clinical effects achieved with HA in the treatment of OA.[12-14] In addition to a purely mechanical effect due to the viscosity of the products (restoration of visco-elastic properties of the synovial fluid: cushioning, lubrication, elasticity), intra-articular HA viscosupplementation is thought to provide a range of biological actions including anti-inflammatory, analgesic, anabolic, and chondroprotective effects that reduce pain and disability and improve joint function.[12-14] 
The term viscoinduction has been coined to describe the phenomenon of the clinical benefits of HA exceeding that of a physical lubricant/cushioning effect alone.

Viscoinduction ensures that clinical efficacy is maintained for several months despite the half-life of intra-articular HA being only a few days.

It has been suggested that exogenous HA induces endogenous HA synthesis, possibly stimulating the regenerative process within the joint.[15] Indeed, in vitro, in studies of synoviocytes from joints of subjects with OA, exogenous HA was associated with de novo synthesis of HA [15]

HAs may also have structure-modifying actions and may, therefore, have benefits on the disease process; however, this effect is still a matter of debate as currently, there is minimal evidence to support a role of HA in OA disease modification.[7]

HA agents are generally administered as a weekly injection over a course of 3 to 5 weeks, and although they have a slower onset of action relative to steroid treatment, the pain relief obtained generally lasts longer - for up to several months.[7]

\section{Commercially available HA derivatives}

A number of different preparations of HA are currently available in Europe and USA (Table 1).[5, 14, 16-19] Each is produced from either rooster combs (avian type) or by recombinant technology (biofermentation) and differs by molecular weight and hence residence time in the joint, and rheological properties.[5, 14, 16-19]

\section{Treatment Guidelines}

HA therapy is recommended in the American College of Rheumatology (ACR) and European League of Arthritis \& Rheumatism (EULAR) guidelines for the management of patients with hip or knee OA, and is advocated for use in those patients who have not responded to other therapies (as discussed above).[7, 8, 20, 21] However, in an effort to minimise cardiovascular, gastrointestinal (ulcers, bleeding) and renal safety concerns with COX-2 selective and other non-selective NSAIDs, and to maximise HA efficacy, other authors propose using an HA earlier in the treatment paradigm for knee $\mathrm{OA}$, and in general as part of a comprehensive treatment strategy.[18]

A Cochrane meta-analysis of 76 trials (including 40 placebo-controlled trials of HA or 
hylan) showed that viscosupplementation is effective in OA of the knee with beneficial effects on pain, function and patient global assessment, especially at the 5 to 13 week post-injection period when pain and function were improved from baseline by $28 \%-54 \%$ and $9 \%-32 \%$, respectively. However, the analysts reported that as there was marked variability between different HAs on different outcome parameters, especially at different time points, conclusions could not be drawn regarding the relative value of each HA product.[22] Although in general, the efficacy of HAs was comparable with NSAIDs, benefits were of longer duration with HAs compared with intra-articular corticosteroids. Few adverse events were reported with the use of HAs, and overall it was surmised that within the constraints of the trial designs (some used small sample size), there were no major safety concerns.

\section{Overview of Sinovial ${ }^{\circledR}$}

Sinovial $^{\circledR}$ (sodium hyaluronate) is a non-modified HA, a linear polymer composed of the disaccharide units $\mathrm{N}$-acetyl-D-glucosamine and $\mathrm{Na}-\mathrm{D}$-glucuronate, linked by glycosidic bonds. It is classified as a medical device; it is a $0.8 \%$ physiological solution of HA $(16 \mathrm{mg} / 2 \mathrm{ml})$ in sodium chloride in a ready to use sterile syringe for intra-articular injection.[23] HA is obtained by biofermentation and undergoes a stringent purification process (in the absence of chemical modification) to produce a highly purified, non-pyrogenic polymer of a defined molecular weight (800-1200 $\mathrm{kDa}$ ) that is completely free from animal proteins.[23]

Sinovial ${ }^{\circledR}$ is indicated in patients undergoing joint replacement and/or supplementation of synovial fluid damaged following degenerative joint disease or trauma; currently, it is used mainly in the knee.[24]

In clinical studies, administration of Sinovial ${ }^{\circledR}$ resulted in a marked reduction in pain, improvement of joint mobility, and decreased use of rescue medication (see later section).[12, 24, 25] Importantly, the effects of Sinovial ${ }^{\circledR}$ are evident from the first injection (out of a cycle of 3 to 5) and last up to 6 months, suggesting a long-lasting carry-over effect of the treatment.[12, 24, 25]

Sinovial ${ }^{\circledR}$ is also available in other ready-to-use formulations; [23] a higher concentration formulation, Sinovial ${ }^{\circledR}$ Forte $1.6 \%(32 \mathrm{mg} / 2 \mathrm{ml})$ for major joint 
lubrication and during an acute attack in active OA, and a lower volume formulation, Sinovial ${ }^{\circledR}$ Mini $0.8 \%(8 \mathrm{mg} / 1 \mathrm{ml})$ for ultrasound-guided infiltration of small joints, e.g. for treatment of rhizarthrosis (OA in the base of the thumb), tenosynovitis (wrist tendonitis), or trigger finger.

\section{Main Differentiating Points from Other HA Derivatives}

\section{Molecular Weight}

HAs of various molecular weights are available (Table 1). Low molecular weight HAs consist of long unbranched chains of natural HA, not chemically modified, e.g. Sinovial $^{\circledR}(800-1200 \mathrm{kDa})$ and Hyalgan ${ }^{\circledR}$ (500-730 kDa). High molecular weight HAs consist of chemically modified cross-linked HA chains (hylans), e.g., Synvisc ${ }^{\circledR}(6,000$ $\mathrm{kDa})$.

The efficacy of intra-articular HA injections may be dependent, in part, on the viscoelastic properties of the HA injected, this being a function of its molecular weight.[9, 13] It was initially suggested that an HA with a higher molecular weight may provide improved clinical benefits.[26-29] However, clinical studies have generally not shown this (as discussed below), and although results of a meta-analysis of 22 studies by Lo et al. suggested greater effects with HA of higher molecular weight, the heterogeneity of the included trials limited the validity of such a definitive conclusion.[28]

In addition, other evidence, including results from large animal models of OA shows that HAs with molecular weight between 500-1000 KDa are more effective than high molecular weight HAs in reducing synovial inflammation and for restoring the rheological properties of synovial fluid.[30] Also, several preclinical studies evaluating joint-structure modification in animal models of OA have reported advantages of using HAs of molecular weight in the low- to mid-range as they can access diseased tissue more easily, suggesting potential for disease modification.[14] Furthermore, some studies show no difference in efficacy but an overall risk: benefit profile favouring lower molecular weight HAs.[31-33] In a post-hoc analysis of a randomised head-to-head study of hylan G-F 20 versus bioengineered high weight hyaluronic acid (Bio-HA), there was no significant difference in response with either treatment $(63 \%$ vs $71 \% ; \mathrm{p}=0.10)$ and both were generally well tolerated; however, the incidence of effusions was greater with hylan G-F 20.[32] Similarly, the meta- 
analysis of Reichenbach et al.[31] evaluated 13 randomised trials in 2,085 patients comparing hylan with HA in the treatment of OA of the knee. When all the trials were considered, the pooled effect size favoured hylan $(-0.27)$; however, the heterogeneity of these trials was considerable, and a further analysis of the more robust studies showed a negligible effect size. Moreover, a safety analysis demonstrated a 2-fold increased risk of local adverse events (pain, swelling or warming to severe inflammation) and flares with hylan.

Thus, a likely explanation for the lack of definitive correlation between HA molecular weight and therapeutic effect may be that the mechanism of action of HA for relief of OA symptoms is an interplay between mechanical and biological effects. In vitro studies have shown that HA has chondroprotective,[34] and anti-inflammatory and structure-modifying effects in synoviocytes through down-regulation of gene expression for various cytokines, aggrecanase-2 and other enzymes;[35] effects thought to occur via CD44-mediated metabolic modulation.[34-36] In addition, the enduring clinical efficacy (months) of intra-articular HA compared with its relatively short half-life may also be accounted for by CD44-mediated metabolic modulation-

\section{Source of hyaluronan}

Sinovial ${ }^{\circledR}$ is obtained by biofermentation, which ensures that the product is pure and free of potentially allergenic animal proteins.[23] Other HAs/hylans, e.g. Hyalgan ${ }^{\circledR}$ and Synvisc ${ }^{\circledR}$ are obtained by extraction from rooster combs (containing avian proteins) and, therefore, may have an increased risk of immunogenicity.[17] In contrast with HAs, cross-linked hylan G-F 20 use has been associated with infrequent but dramatic pseudoseptic acute local reactions.[37-39] The incidence $(8-27 \%)$ and characteristics of pseudosepsis (i.e., severe acute inflammatory reactions that are clinically distinct from local inflammatory reactions) with the use of Hylan from reports published up to 2003 (4 clinical and 5 case studies) were collated by Goldberg and Coutts.[39] Characteristics included severe inflammation of the joint, often associated with significant cellular effusion and pain generally occurring within 24-72 hours post intra-articular hylan injection; first occurrence after exposure to second or third injection of first course, or post first injection of a repeat course; and generally not self-limiting but requiring clinical intervention. Despite a lack of understanding of both the aetiology of pseudosepsis and the long-term effects of these 
local immunological reactions in the knee, such events would be expected to incur addition socio-economic costs.

Further evidence for the potential increased immunogenicity with hylan comes from a meta-analysis (discussed above) that showed no superior effectiveness of hylan over $\mathrm{HA}$ in the treatment of OA of the knee, but rather an increased risk of local adverse events.[31] It is established that cross-linked proteins are relatively more immunogenic. In addition, it has been proposed that contaminating chicken proteins and other components of rooster combs potentially present during the cross-linking process of hylans could result in the production of novel epitopes that may induce pseudosepsis in sensitised subjects.[39]

\section{Clinical Evidence for Hyaluronan Derivatives}

\section{Knee OA}

The efficacy of intra-articular HA or hylan in the relief of pain and improvement in joint function in patients with OA of the knee (of varying severity, Larsen grade I-V) has been shown in numerous controlled and observational clinical studies (Table 2, 3, 4).

In placebo-controlled trials (some used a negligible concentration of HA in the vehicle solution to maintain a viscous appearance) of intra-articular HA, superior and sustained relief of pain and functional ability were generally shown in the absence of safety and tolerability concerns, with effects seen from as early as 1 week after the first injection, and generally at week 3 , then lasting up to 6 months (Table 2). Various preparations of HA and dosing schedules (3-5 consecutive once-weekly injections) were used in these trials, and concomitant analgesic therapy was permitted in some studies. Carrabba et al. showed that 3 or 5 once-weekly intra-articular HA injections were superior to a single injection, providing relief of symptoms for up to 2 months (Table 2).[40] Longer-term (up to 52 weeks) functional improvement was seen with a course of 4 weekly injections,[41] and Listrat et al. showed that with an increased HA dosing schedule (9 injections over 9 months), there was less structural deterioration at 1 year compared with control,[42] providing evidence of a delay in progression of structural deterioration in the knee with HA. 
In non comparative trials, both a rapid onset of action (one week after injection)[43] and subsequent symptom relief with a second cycle of treatment (6 months after the first) that was comparable to that obtained with the first cycle was shown.[44]

In trials of HA versus active treatment, efficacy was comparable with NSAID therapy,[45] and of longer duration than that of corticosteroid treatment,[46] findings that are in agreement with those of the Cochrane review discussed above.[22] In one large study [45], not only HA was superior to placebo for reduction in pain (from 4-26 weeks), it was also as effective as twice daily naproxen (from 4-26 weeks) with significantly fewer gastrointestinal adverse events. The investigators concluded that HA is an effective therapeutic alternative to NSAIDs for patients not responding to non-pharmacologic therapy and non-opiate analgesics, especially for those with a history of NSAID intolerance, e.g. the elderly or patients with active ulcer disease.[45] In a study in patients with inflammatory OA of the knee, although there was a high dropout rate, it was shown that HA provided similar efficacy as corticosteroid treatment for relief of pain over the first 4 weeks, while during the 6month follow-up period, patients remaining in the study had greater pain relief with HA.[46]

Trials of hylan preparations for OA of the knee are few and have been mostly limited to 12-weeks duration (Table 3). In one study, hylan was superior to saline control for pain relief and for increasing mobility,[47] while in another study, both hylan alone, and as adjunct to NSAID therapy was as effective as continuous NSAID therapy, although the incidence of adverse events was greater with hylan.[48] One small study showed intra-articular hylan was superior to NSAID therapy,[49] while in another, hylan was as effective as corticosteroid treatment, but was associated with an acute local reaction causing the affected patient to withdraw.[50]

Head-to-head trials of intra-articular HA versus hylan are also few (Table 4). In the first trial, a small 12-week study, significantly greater pain relief with hylan than a lower-molecular-weight hyaluronan was shown ( $\mathrm{p}<0.05)$.[29] Notably, one uncontrolled study in patients with advanced OA of the knee (candidates for total knee replacement) showed similar improvements at 1-year of follow-up with both HA and hylan;[51] however, a 1-year placebo-controlled trial failed to show any significant difference in treatment effect between intra-articular placebo, HA or hylan.[52] 


\section{Hip OA}

OA of the hip is the second most common form of arthritis after OA of the knee, and is also a source of chronic pain, functional impairment and disability, especially in the elderly. Viscosupplementation with intra-articular HA has also been studied in OA of the hip, although to a lesser extent. There is some difficulty and potential danger associated with intra-articular injection of the hip (guided by fluoroscopy or ultrasound) due to the anatomical features of the hip joint and its locality in relation to the femoral neurovascular structure. Of note, the ease and safety of sonographicallyguided intra-articular HA injections for OA of the hip has been shown.[53]

A number of recent reviews[5, 19, 54] and a meta-analysis[55] have provided an overview of studies to date of viscosupplementation with HA in hip OA. There is some evidence that efficacy may be greater in cases of less radiographic changes of hip OA,[56] and may last up to 3 months post first injection with sustained benefits with further injections.[57]

Among eight trials evaluated in a systematic review, only 2 were controlled leading to the conclusion that lack of control groups, small sample size, variable dosing, short follow-up (3-6 months) and variability in outcome measures limited valid recommendations, although symptomatic relief for pain and function was evident in some studies, [58] with efficacy generally seen at 1 month post injection.[55] These studies used 1-5 injections of either low[59] or high[58] molecular weight HA, and no marked between-treatment differences in clinical efficacy were apparent.

Results of available controlled trials have also been inconclusive. One study showed no significant difference between HA ( 3 injections), saline and corticosteroid use at 3 month follow-up, despite some level of clinical benefit with corticosteroid and HA use.[59] Findings from an uncontrolled study by Conrozier et al.[60] suggested that a single injection of HA was efficacious in hip OA; however, a recent, randomised, placebo-controlled trial in 85 patients showed no significant difference between placebo and a single intra-articular injection of HA for reduction in pain at 3 month follow-up.[61] Clearly, large well-controlled trials of HA in hip OA are warranted. 


\section{Shoulder pain}

Several studies have provided preliminary support regarding the safety and the clinical efficacy of HA injections for the treatment of persistent shoulder pain. A number of shoulder pain aetiologies were evaluated, including osteoarthritis, [62, 63] rotator cuff tear,[64, 65] periarthritis,[66] Duplay's disease with or without osteoarthritis,[67] and frozen shoulder (adhesive capsulitis)[68, 69] in which USguided intrarticular injections might offer advantages over a blind technique.[70] In a randomised, double-blind, parallel-design, phosphate-buffered saline solutioncontrolled study, Blaine et al.[65] showed that sodium hyaluronate (500 to $730 \mathrm{kDa}$ ) was effective and well tolerated for the treatment of osteoarthritis and persistent shoulder pain refractory to other standard nonoperative interventions.

However, additional well-controlled comparative trials are needed to identify the most effective interventions in patients with persistent shoulder pain of different aetiology.

\section{Other joints}

The feasibility of viscosupplementation with intra-articular HA in joints other than the knee and hip is under investigation, reviewed previously elsewhere[5]. Surprisingly, although the ankle bears considerable weight and is more frequently injured than any other joint in the body, the prevalence of symptomatic OA of the ankle is an estimated 9 times lower than that of the knee or hip.[71] Small studies to date on the use of intra-articular HA in patients with OA of the ankle have shown benefits compared with placebo for up to 3[72] or 6 months[73], comparable functional improvement as that attained with exercise therapy[71], and symptom relief for up to 12 months in an uncontrolled trial.[74]

Currently, there are few treatment options for OA of the thumb. Notably, serum levels of HA have been reported to be increased in erosive compared with non-erosive OA of the hand, suggesting its utility as a surrogate marker for radiographic progression of OA of the hand.[75] A preliminary small study in 16 patients with OA in the trapeziometacarpal joint showed reductions in pain (maximal at 5 months) with 5 weekly injections of intra-articular HA.[76] Among subsequent randomised studies in similar populations, one in 52 patients showed that both HA and corticosteroid 
treatment were effective in reducing pain, although HA was more effective in improving some fine hand functions for up to 6 months.[77] Although one open-label study in 40 female patients with trapeziometacarpal joint OA showed corticosteroid treatment was superior to 3 weekly injections of HA in reducing pain and improving hand function, [78] another randomised study in which 56 patients received 3 weekly intra-articular injections showed maximum pain relief at week 2 or 3 with steroid treatment, and at week 26 with HA which thus showed superior long-term improvements.[79]

A preliminary study of viscosupplementation with HA in OA of the elbow,[80] has been exploratory, while one study in patients with OA of the jaw [81] showed superior results compared with corticosteroid injections; further studies are warranted.

\section{Limitations of Clinical Evidence}

Results of systematic reviews and meta-analyses are contradictory, e.g., in knee OA[22, 28, 82-85] and hip OA.[54] These have varied regarding the extent of the clinical benefit of various HA products.[86] The discrepancy in data might be due to differences in study design (e.g., some studies were uncontrolled, small and permitted the use of rescue analgesia), clinical endpoints used, evaluation methods and absence of intention-to-treat analysis, patient populations, as well as study drugs/regimens used. Clearly, randomised, controlled trials with larger patient numbers and longer follow-up times are required to confirm promising preliminary data (particularly in non-knee OA) and to identify the characteristics of patients most likely to benefit from this treatment, i.e., in terms of age, disease severity, etc..

One of the limitations of HA therapy is that it can be difficult to ensure that the intraarticular injections are actually given into the joint capsule; ultrasound has been used to guide HA administration in hip and hand OA.[53, 57, 87]

\section{Clinical Evidence for Sinovial $^{\circledR}$}

To date, several clinical studies have demonstrated the tolerability and efficacy of Sinovial ${ }^{\circledR}$ in the management of OA of the knee. A 24-week, prospective, longitudinal, open-label, tolerability and efficacy study evaluated 5 once-weekly 
intra-articular injections of Sinovial ${ }^{\circledR}$ in 63 patients (26 males/37 females of mean age 60 [range 29-83] years and weight $81 \pm 12 \mathrm{~kg}$ ) with chronic primary or secondary knee OA (of not $>12$ months old and with a Kellgren and Lawrence radiographic grade of II-IV) and a baseline 0-100 mm VAS score of >30 mm.[24] The most frequently reported adverse event was pain and/or a burning sensation at the injection site (with 18 of 310 injections). Only four other adverse events were considered to be probably or very probably related to treatment. These occurred at an incidence of $1.3 \%$ of all injections and in $6.3 \%$ of all treated patients, and were generally mild and transient (tension in knee lasting 2 days, vasovagal collapse on injection lasting 5 minutes, and a skin haematoma at injection site lasting 7 days) or moderate in intensity (fever and diarrhoea lasting 6-7 hours). In the efficacy analysis, the total score for the self administered Westminster Ontario and McMaster Universities (WOMAC) OA Index Questionnaire was significantly reduced from 4.0 at baseline, to 3.6 at week 2 $(\mathrm{p}=0.0011)$ and progressively until week $6(2.6 ; \mathrm{p}<0.0001)$, and was sustained until week 24 (2.4; $\mathrm{p}<0.0001)$ (figure 1). WOMAC subscore analysis showed a similar trend for reduction in pain, stiffness, and physical function, with statistical significance versus baseline first seen at weeks 4, 6 and 6, respectively, for these scores.

Further evidence lends support to the tolerability and efficacy of Sinovial ${ }^{\circledR}$ in a reallife scenario. A retrospective observational study conducted in patients with knee OA suggested that the intra-articular injection of Sinovial ${ }^{\circledR}$ is associated with improved knee function, less pain and less need for pain medications [88]. In total, 408 patients (146 men and 262 women; mean age: men, 63 years, women 67 years [range: 26-92 years]) were included in the study; $65.4 \%$ of them presented OA symptoms for $>2$ years. Overall, knee function was judged as "better" or "much better since injection by $64.5 \%$ of patients and $68.3 \%$ of physicians. At study enrolment, 8 months after injection (mean time), $44.3 \%$ of patients considered their knee pain to be "low" or "null" during the day and $76.4 \%$ during the night. Moreover, in the 10 months after the administration of Sinovial ${ }^{\circledR}$, NSAIDs were prescribed in only $31 \%$ of the 113 patients treated with these drugs during the 2 months prior to injection. Local adverse events were reported in $4 \%$ of patients, whereas no systemic adverse events were observed.

Another retrospective observational study, conducted in 40 (12 male and 28 female) 
patients with primary or secondary symptomatic OA of the knee showed that a cycle of 5 once-weekly injections of Sinovial ${ }^{\circledR}$ was well tolerated and reduced pain and rescue medication use.[12] The mean age of the study population was 58 years (range: 18-82 years) and patients had experienced OA for a mean duration of 4.2 (range 2.5-9.3) years that was predominantly diagnosed as of mild to moderate severity, but was more severe in 3 patients. The rates of good/excellent overall judgement of general tolerance to treatment, as assessed by both investigator and patient was $95 \%$ at week 5 and increased to $97.5 \%$ at week 7 . Injection site pain (slight to moderate burning sensation) that was reported by $40 \%$ of patients was most frequently reported at the first injection, and generally resolved after a few minutes. There was a complete absence of systemic or serious adverse events. Mean Lequesne's Algo-Functional Index score decreased from baseline (7.9) by $40 \%$ after only 3 injections and by $59 \%$ at the 7 week assessment (figure 2); reductions in scores for pain level correlated with these results. In addition, use of rescue medication (NSAID or paracetamol) was progressively and markedly reduced from baseline to week 7 .

A course of 3 intra-articular weekly injections of Sinovial ${ }^{\circledR} 0.8 \%(16 \mathrm{mg} / 2 \mathrm{ml})$ $(n=183)$ was shown to be non-inferior to 3 intra-articular weekly injections of Synvisc $^{\circledR}$ (Hylan G-F 20) $(16 \mathrm{mg} / 2 \mathrm{ml})(\mathrm{n}=171)$ in a recent 26 -week double-blind, randomised, multicentre, parallel-group study in 354 patients with moderate-to-severe symptomatic OA of the knee.[89] The study population was predominantly female (74\%), of mean age 64 (range 42-80) years, and weight $75 \mathrm{~kg}$. The preliminary analysis showed that mean improvement on the WOMAC index pain subscore (measured on a 0-100 mm VAS scale) from baseline to 6 months did not differ significantly $\left(\mathrm{p}=\right.$ n.s.) between the Sinovial ${ }^{\circledR}-(-33.5[-59.9 \%])$ and the Synvisc ${ }^{\circledR}-$ treated groups (-34.5 [62.2\%]) (figure 3). In addition, global tolerance, as assessed by both patients and the investigator, was rated as good/very good in more than $95 \%$ of patients in both groups ( $\mathrm{p}=$ n.s.). One serious adverse event (gonarthritis) related to the treatment with Synvisc ${ }^{\circledR}$ was reported.

Data on the use of Sinovial ${ }^{\circledR}$ in joints other than the knee are also available. In an open-label, uncontrolled, efficacy study, 42 patients (38 female, mean age 65 years) with OA of the thumb randomly received 1,2 , or 3 once-weekly intra-articular injections of Sinovial ${ }^{\circledR} 1 \mathrm{ml}$ into the carpometacarpal joint of the thumb under fluoroscopic guidance.[25] Improvements in pain and function were seen as early as 1 
month and were sustained at 3 months. There was no significant difference betweentreatment for improvements in pain (VAS) and function (Dreiser index), indicating no notable dose effect over the 3 month study duration. However, reduction in pain (mean baseline VAS score was 58) was significant at 3 month assessment compared with baseline and month 1 for patients that received $2(\mathrm{p}=0.01$ for both) or 3 injections $(\mathrm{p} \leq 0.002)$. This was not seen for the 1 injection cohort. Although improvements in function were seen in all groups from baseline to month 3 , statistical significance was not shown. Sinovial ${ }^{\circledR}$ was generally well tolerated with moderate pain, swelling, heat and redness, or any combination of these events, occurring in about $30 \%$ of all cases, but these events were mostly resolved in less than 3 hours, or 2 days in a few cases.

Recently a clinical prospective trial on 100 consecutive patients was performed in order to analyse the efficacy and safety of Sinovial ${ }^{\circledR}$ in subsets of patients with persistent shoulder pain of different artiology (subacromial bursitis, partial-thickness rotator cuff tear, full-thickness rotator cuff tear without osteoarthritis and rotator cuff arthropathy).(Gigante et al., in press) Results showed that Sinovial ${ }^{\circledR}$ was effective and well tolerated in all subsets of patients. Moreover, and differing from other studies,[65] in this experience hyaluronan injections were effective also in patients who experience persistent shoulder pain without established OA.

Preliminary evidence also suggests that the use of Sinovial ${ }^{\circledR}$ Mini $0.8 \%(8 \mathrm{mg} / 1 \mathrm{ml})$ in ultrasound-guided infiltration of small joints in patients with rhizarthrosis, tenosynovitis or trigger finger is helpful in alleviating painful symptoms and improving functionality.[90](Dr Callegari, unpublished observation) In an Italian reallife experience, conducted in a specialised centre, 270 patients (58 males; mean age: 56.5 years [range 30-83 years]) affected by rhizarthrosis were treated with this therapeutic strategy between 2004 and 2009.(Dr Callegari, unpublished observation) Rhizarthrosis was bilateral in 228 patients. A pilot analysis of this sample $(n=20$; patients with symptomatic OA of the hand other than rhizarthrosis, those receiving steroids or HA in the 6 months prior to the analysis and those with grade IV rhizarthrosis were excluded) evaluated articular pain (VAS score), joint mobility, and hand strength (grip strength, lateral pinch and tip pinch) at baseline and three months after the injection of Sinovial ${ }^{\circledR}$ Mini. Overall, all parameters improved (Table 5), even if a statistical analysis was not performed due to the small sample size. Eighteen out 
of 20 patients rated the treatment as "very satisfactory" and 2 as "moderately satisfactory". In another pilot analysis on the same sample, patients received (a) maintenance Sinovial ${ }^{\circledR}$ Mini injections 4 and 8 months after the first administration; (b) maintenance injection only 8 months after the first administration; or (c) no maintenance injection ( $\mathrm{n}=10$ in each group; the same exclusion criteria of the abovedescribed pilot analysis). The evaluation of pain in the year following the first administration suggested that the injection of Sinovial ${ }^{\circledR}$ Mini every 4 months may result in greater maintenance of pain relief overall (Table 6).(Dr Callegari, unpublished observation) Further studies are ongoing in the same centre to evaluate the effectiveness of Sinovial ${ }^{\circledR}$ Mini $0.8 \%$ in ultrasound-guided infiltration of other small joints.

\section{Conclusion}

OA is a major cause of chronic pain, disability and reduced quality of life.

Furthermore, the clinical and economic burden of OA is significant, and is increasing due to demographic changes, longer life expectancy, higher levels of obesity, and reduced levels of physical fitness.

Many patients do not respond to management strategies involving nonpharmacological interventions and analgesic/NSAID therapy. Viscosupplementation, via intra-articular injection of HA derivatives, appears to restore the physiological conditions of the joint, thus reducing pain and improving joint function. Several HA agents are currently available, although the current evidence is not sufficient to enable differentiation among the various products in terms of relative efficacy.

HA side effects are generally limited to injection site reactions, although high molecular weight cross-linked hylans and products sourced from avian sources may be associated with infrequent but serious adverse reactions including pseudosepsis. Sinovial ${ }^{\circledR}$ is indicated in patients undergoing joint replacement and/or supplementation of damaged synovial fluid following degenerative joint disease or trauma, and the available studies show it to be an effective and well tolerated therapy for improvement of OA pain and dysfunction. In addition, the reduced volume formulation $(1 \mathrm{ml})$ of Sinovial ${ }^{\circledR}$ at a concentration of $0.8 \%$ is indicated for ultrasound- 
guided infiltration of small joints in patients with rhizarthrosis, tenosynovitis or trigger finger.

Sinovial ${ }^{\circledR}$ viscosupplementation, thanks to its pain relieving action and the proved functional improvement associated with the therapy, stands as a valuable treatment approach for patients with different forms of OA.

\section{Acknowledgments}

We thank Nila Bhana of inScience Communications, a Wolters Kluwer business, who provided medical writing support funded by IBSA. The authors have no conflicts of interest that are directly relevant to the content of this review. 


\section{References}

1. National Institute for Clinical Excellence. OSTEOARTHRITIS National clinical guideline for care and management in adults. 2009 [cited 20094 Sept]; Available from: http://www.nice.org.uk/nicemedia/pdf/CG059FullGuideline.pdf 2. European Commission. Indicators for Monitoring Musculoskeletal Conditions Project. 2009 [cited 20093 Sept ]; Available from: http://ec.europa.eu/health/ph_information/dissemination/diseases/musculo_en.htm 3. World Health Organization. The burden of musculoskeletal conditions at the start of the new millennium. WHO Technical Report Series 9192003 [cited 20094 Sept]; Available from: http://whqlibdoc.who.int/trs/WHO_TRS_919.pdf 4. Hochberg MC (2000) Role of intra-articular hyaluronic acid preparations in medical management of osteoarthritis of the knee. Semin Arthritis Rheum 30(2 Suppl 1):2-10.

5. Strauss EJ, Hart JA, Miller MD, Altman RD, Rosen JE (2009) Hyaluronic acid viscosupplementation and osteoarthritis: current uses and future directions. Am J Sports Med 37(8):1636-44.

6. Altman RD (1990) Osteoarthritis. Differentiation from rheumatoid arthritis, causes of pain, treatment. Postgrad Med 87(3):66-72, 7-8.

7. Jordan KM, Arden NK, Doherty M, Bannwarth B, Bijlsma JW, Dieppe P, et al. (2003) EULAR Recommendations 2003: an evidence based approach to the management of knee osteoarthritis: Report of a Task Force of the Standing Committee for International Clinical Studies Including Therapeutic Trials (ESCISIT). Ann Rheum Dis 62(12):1145-55.

8. Zhang W, Doherty M, Arden N, Bannwarth B, Bijlsma J, Gunther KP, et al. (2005) EULAR evidence based recommendations for the management of hip osteoarthritis: report of a task force of the EULAR Standing Committee for International Clinical Studies Including Therapeutics (ESCISIT). Ann Rheum Dis 64(5):669-81.

9. Balazs EA, Denlinger JL (1993) Viscosupplementation: a new concept in the treatment of osteoarthritis. J Rheumatol Suppl 39:3-9.

10. Dahl LB, Dahl IM, Engstrom-Laurent A, Granath K (1985) Concentration and molecular weight of sodium hyaluronate in synovial fluid from patients with rheumatoid arthritis and other arthropathies. Ann Rheum Dis 44(12):817-22.

11. Balazs E, editor. The physical properties of synovial fluid and the specific role of hyaluronic acid; 1982.

12. Castellacci E, Polieri T (2004) Antalgic effect and clinical tolerability of hyaluronic acid in patients with degenerative diseases of knee cartilage: an outpatient treatment survey. Drugs Exp Clin Res 30(2):67-73.

13. Moreland LW (2003) Intra-articular hyaluronan (hyaluronic acid) and hylans for the treatment of osteoarthritis: mechanisms of action. Arthritis Res Ther 5(2):5467.

14. Vitanzo PC, Jr., Sennett BJ (2006) Hyaluronans: is clinical effectiveness dependent on molecular weight? Am J Orthop 35(9):421-8.

15. Dixon AS, Jacoby RK, Berry H, Hamilton EB (1988) Clinical trial of intraarticular injection of sodium hyaluronate in patients with osteoarthritis of the knee. Curr Med Res Opin 11(4):205-13.

16. Maheu E, Ayral X, Dougados M (2002) A hyaluronan preparation (500-730 $\mathrm{kDa}$ ) in the treatment of osteoarthritis: a review of clinical trials with Hyalgan. Int $\mathbf{J}$ Clin Pract 56(10):804-13. 
17. Hamburger MI, Lakhanpal S, Mooar PA, Oster D (2003) Intra-articular hyaluronans: a review of product-specific safety profiles. Semin Arthritis Rheum 32(5):296-309.

18. Brzusek D, Petron D (2008) Treating knee osteoarthritis with intra-articular hyaluronans. Curr Med Res Opin 24(12):3307-22.

19. Migliore A, Granata M (2008) Intra-articular use of hyaluronic acid in the treatment of osteoarthritis. Clin Interv Aging 3(2):365-9.

20. ACR (2000) Recommendations for the medical management of osteoarthritis of the hip and knee: 2000 update. American College of Rheumatology Subcommittee on Osteoarthritis Guidelines. Arthritis Rheum 43(9):1905-15.

21. Roddy E, Doherty M (2003) Guidelines for management of osteoarthritis published by the American College of Rheumatology and the European League Against Rheumatism: why are they so different? Rheum Dis Clin North Am 29(4):717-31.

22. Bellamy N, Campbell J, Robinson V, Gee T, Bourne R, Wells G (2006) Viscosupplementation for the treatment of osteoarthritis of the knee. Cochrane Database Syst Rev (2):CD005321.

23. IBSA. Sinovial ${ }^{\circledR}$ : Summary of Product Characteristics; 2009.

24. Theiler R, Bruhlmann P (2005) Overall tolerability and analgesic activity of intra-articular sodium hyaluronate in the treatment of knee osteoarthritis. Curr Med Res Opin 21(11):1727-33.

25. Roux C, Fontas E, Breuil V, Brocq O, Albert C, Euller-Ziegler L (2007) Injection of intra-articular sodium hyaluronidate (Sinovial) into the carpometacarpal joint of the thumb (CMC1) in osteoarthritis. A prospective evaluation of efficacy. Joint Bone Spine 74(4):368-72.

26. Gomis A, Pawlak M, Balazs EA, Schmidt RF, Belmonte C (2004) Effects of different molecular weight elastoviscous hyaluronan solutions on articular nociceptive afferents. Arthritis Rheum 50(1):314-26.

27. Weiss C, Band PA (1999) Basic principles underlying the development of viscosupplementation for the treatment of osteoarthritis. J Clin Rheumatol 3:S2-11.

28. Lo GH, LaValley M, McAlindon T, Felson DT (2003) Intra-articular hyaluronic acid in treatment of knee osteoarthritis: a meta-analysis. JAMA 290(23):3115-21.

29. Wobig M, Bach G, Beks P, Dickhut A, Runzheimer J, Schwieger G, et al. (1999) The role of elastoviscosity in the efficacy of viscosupplementation for osteoarthritis of the knee: a comparison of hylan G-F 20 and a lower-molecularweight hyaluronan. Clin Ther 21(9):1549-62.

30. Ghosh P, Guidolin D (2002) Potential mechanism of action of intra-articular hyaluronan therapy in osteoarthritis: are the effects molecular weight dependent? Semin Arthritis Rheum 32(1):10-37.

31. Reichenbach S, Blank S, Rutjes AW, Shang A, King EA, Dieppe PA, et al. (2007) Hylan versus hyaluronic acid for osteoarthritis of the knee: a systematic review and meta-analysis. Arthritis Rheum 57(8):1410-8.

32. Onel E, Kolsun K, Kauffman JI (2008) Post-Hoc analysis of a head-to-head hyaluronic acid comparison in knee osteoarthritis using the 2004 OMERACT-OARSI responder criteria. Clin Drug Investig 28(1):37-45.

33. Kotevoglu N, Iyibozkurt PC, Hiz O, Toktas H, Kuran B (2006) A prospective randomised controlled clinical trial comparing the efficacy of different molecular weight hyaluronan solutions in the treatment of knee osteoarthritis. Rheumatol Int 26(4):325-30. 
34. Brun P, Panfilo S, Daga Gordini D, Cortivo R, Abatangelo G (2003) The effect of hyaluronan on CD44-mediated survival of normal and hydroxyl radicaldamaged chondrocytes. Osteoarthritis Cartilage 11(3):208-16.

35. Wang CT, Lin YT, Chiang BL, Lin YH, Hou SM (2006) High molecular weight hyaluronic acid down-regulates the gene expression of osteoarthritisassociated cytokines and enzymes in fibroblast-like synoviocytes from patients with early osteoarthritis. Osteoarthritis Cartilage 14(12):1237-47.

36. Chou CL, Li HW, Lee SH, Tsai KL, Ling HY (2008) Effect of intra-articular injection of hyaluronic acid in rheumatoid arthritis patients with knee osteoarthritis. $\mathrm{J}$ Chin Med Assoc 71(8):411-5.

37. Leopold SS, Warme WJ, Pettis PD, Shott S (2002) Increased frequency of acute local reaction to intra-articular hylan GF-20 (synvisc) in patients receiving more than one course of treatment. J Bone Joint Surg Am 84-A(9):1619-23.

38. Pullman-Mooar S, Mooar P, Sieck M, Clayburne G, Schumacher HR (2002) Are there distinctive inflammatory flares after hylan g-f 20 intraarticular injections? J Rheumatol 29(12):2611-4.

39. Goldberg VM, Coutts RD (2004) Pseudoseptic reactions to hylan viscosupplementation: diagnosis and treatment. Clin Orthop Relat Res (419):130-7. 40. Carrabba M, Paresce E, Angelini M, al. e (1995) The safety and efficacy of different dose schedules of hyaluronic acid in the treatment of painful osteoarthritis of the knee with joint effusion. Eur J Rheumatol Inflamm 15:25-31.

41. Dougados M, Nguyen M, Listrat V, Amor B (1993) High molecular weight sodium hyaluronate (hyalectin) in osteoarthritis of the knee: a 1 year placebocontrolled trial. Osteoarthritis Cartilage 1(2):97-103.

42. Listrat V, Ayral X, Patarnello F, Bonvarlet JP, Simonnet J, Amor B, et al. (1997) Arthroscopic evaluation of potential structure modifying activity of hyaluronan (Hyalgan) in osteoarthritis of the knee. Osteoarthritis Cartilage 5(3):15360 .

43. Novaes AC, Schaiquevich P, Nasswetter G (2005) Multicenter study of hyaluronic acid obtained by biotechnology to evaluate clinical efficacy and safety in knee osteoarthritis. Int J Clin Pharmacol Res 25(1):1-7.

44. Petrella RJ (2005) Hyaluronic acid for the treatment of knee osteoarthritis: long-term outcomes from a naturalistic primary care experience. Am J Phys Med Rehabil 84(4):278-83; quiz 84, 93.

45. Altman RD, Moskowitz R (1998) Intraarticular sodium hyaluronate (Hyalgan) in the treatment of patients with osteoarthritis of the knee: a randomized clinical trial. Hyalgan Study Group. J Rheumatol 25(11):2203-12.

46. Jones AC, Pattrick M, Doherty S, Doherty M (1995) Intra-articular hyaluronic acid compared to intra-articular triamcinolone hexacetonide in inflammatory knee osteoarthritis. Osteoarthritis Cartilage 3(4):269-73.

47. Wobig M, Dickhut A, Maier R, Vetter G (1998) Viscosupplementation with hylan G-F 20: a 26-week controlled trial of efficacy and safety in the osteoarthritic knee. Clin Ther 20(3):410-23.

48. Adams ME, Atkinson MH, Lussier AJ, Schulz JI, Siminovitch KA, Wade JP, et al. (1995) The role of viscosupplementation with hylan G-F 20 (Synvisc) in the treatment of osteoarthritis of the knee: a Canadian multicenter trial comparing hylan G-F 20 alone, hylan G-F 20 with non-steroidal anti-inflammatory drugs (NSAIDs) and NSAIDs alone. Osteoarthritis Cartilage 3(4):213-25.

49. Dickson DJ, Hosie G, English JR, al. e (2001) A double-blind, placebocontrolled comparison of hylan G-F 20 against diclofenac in knee osteoarthritis. J 
Drug Assessment 4:179-90.

50. Leopold SS, Redd BB, Warme WJ, Wehrle PA, Pettis PD, Shott S (2003)

Corticosteroid compared with hyaluronic acid injections for the treatment of osteoarthritis of the knee. A prospective, randomized trial. J Bone Joint Surg Am 85A(7):1197-203.

51. Karatosun V, Unver B, Gocen Z, Sen A (2005) Comparison of two hyaluronan drugs in patients with advanced osteoarthritis of the knee. A prospective, randomized, double-blind study with long term follow-up. Clin Exp Rheumatol 23(2):213-8.

52. Karlsson J, Sjogren LS, Lohmander LS (2002) Comparison of two hyaluronan drugs and placebo in patients with knee osteoarthritis. A controlled, randomized, double-blind, parallel-design multicentre study. Rheumatology 41(11):1240-8.

53. Pourbagher MA, Ozalay M, Pourbagher A (2005) Accuracy and outcome of sonographically guided intra-articular sodium hyaluronate injections in patients with osteoarthritis of the hip. J Ultrasound Med 24(10):1391-5.

54. Abate M, Pelotti P, De Amicis D, Di Iorio A, Galletti S, Salini V (2008)

Viscosupplementation with hyaluronic acid in hip osteoarthritis (a review). Ups J Med Sci 113(3):261-77.

55. Fernandez Lopez JC, Ruano-Ravina A (2006) Efficacy and safety of intraarticular hyaluronic acid in the treatment of hip osteoarthritis: a systematic review. Osteoarthritis Cartilage 14(12):1306-11.

56. Gaston MS, Tiemessen CH, Philips JE (2007) Intra-articular hip

viscosupplementation with synthetic hyaluronic acid for osteoarthritis: efficacy, safety and relation to pre-injection radiographs. Arch Orthop Trauma Surg 127(10):899-903. 57. Migliore A, Tormenta S, Massafra U, Martin Martin LS, Carloni E, Padalino C, et al. (2006) [18-month observational study on efficacy of intraarticular hyaluronic acid (Hylan G-F 20) injections under ultrasound guidance in hip osteoarthritis]. Reumatismo 58(1):39-49.

58. Berg P, Olsson U (2004) Intra-articular injection of non-animal stabilised hyaluronic acid (NASHA) for osteoarthritis of the hip: a pilot study. Clin Exp Rheumatol 22(3):300-6.

59. Qvistgaard E, Christensen R, Torp-Pedersen S, Bliddal H (2006) Intraarticular treatment of hip osteoarthritis: a randomized trial of hyaluronic acid, corticosteroid, and isotonic saline. Osteoarthritis Cartilage 14(2):163-70.

60. Conrozier T, Couris CM, Mathieu P, Merle-Vincent F, Piperno M, Coury F, et al. (2009) Safety, efficacy and predictive factors of efficacy of a single intra-articular injection of non-animal-stabilized-hyaluronic-acid in the hip joint: results of a standardized follow-up of patients treated for hip osteoarthritis in daily practice. Arch Orthop Trauma Surg 129(6):843-8.

61. Richette P, Ravaud P, Conrozier T, Euller-Ziegler L, Mazieres B, Maugars Y, et al. (2009) Effect of hyaluronic acid in symptomatic hip osteoarthritis: a multicenter, randomized, placebo-controlled trial. Arthritis Rheum 60(3):824-30.

62. Moskowitz RW, Blaine TA (2005) An overview of treatment options for persistent shoulder pain. Am J Orthop 34(12 Suppl):10-5.

63. Silverstein E, Leger R, Shea KP (2007) The use of intra-articular hylan G-F 20 in the treatment of symptomatic osteoarthritis of the shoulder: a preliminary study. Am J Sports Med 35(6):979-85.

64. Shibata Y, Midorikawa K, Emoto G, Naito M (2001) Clinical evaluation of sodium hyaluronate for the treatment of patients with rotator cuff tear. J Shoulder Elbow Surg 10(3):209-16.

65. Blaine T, Moskowitz R, Udell J, Skyhar M, Levin R, Friedlander J, et al. 
(2008) Treatment of persistent shoulder pain with sodium hyaluronate: a randomized, controlled trial. A multicenter study. J Bone Joint Surg Am 90(5):970-9.

66. Itokazu M, Matsunaga T (1995) Clinical evaluation of high-molecular-weight sodium hyaluronate for the treatment of patients with periarthritis of the shoulder.

Clin Ther 17(5):946-55.

67. Leardini G, Perbellini A, Franceschini M, Mattara L (1988) Intra-articular injections of hyaluronic acid in the treatment of painful shoulder. Clin Ther 10(5):521-6.

68. Calis M, Demir H, Ulker S, Kirnap M, Duygulu F, Calis HT (2006) Is intraarticular sodium hyaluronate injection an alternative treatment in patients with adhesive capsulitis? Rheumatol Int 26(6):536-40.

69. Tamai K, Mashitori H, Ohno W, Hamada J, Sakai H, Saotome K (2004) Synovial response to intraarticular injections of hyaluronate in frozen shoulder: a quantitative assessment with dynamic magnetic resonance imaging. J Orthop Sci 9(3):230-4.

70. Lee HJ, Lim KB, Kim DY, Lee KT (2009) Randomized controlled trial for efficacy of intra-articular injection for adhesive capsulitis: ultrasonography-guided versus blind technique. Arch Phys Med Rehabil 90(12):1997-2002.

71. Karatosun V, Unver B, Ozden A, Ozay Z, Gunal I (2008) Intra-articular hyaluronic acid compared to exercise therapy in osteoarthritis of the ankle. A prospective randomized trial with long-term follow-up. Clin Exp Rheumatol 26(2):288-94.

72. Cohen MM, Altman RD, Hollstrom R, Hollstrom C, Sun C, Gipson B (2008) Safety and efficacy of intra-articular sodium hyaluronate (Hyalgan) in a randomized, double-blind study for osteoarthritis of the ankle. Foot Ankle Int 29(7):657-63.

73. Salk RS, Chang TJ, D'Costa WF, Soomekh DJ, Grogan KA (2006) Sodium hyaluronate in the treatment of osteoarthritis of the ankle: a controlled, randomized, double-blind pilot study. J Bone Joint Surg Am 88(2):295-302.

74. Sun SF, Chou YJ, Hsu CW, Hwang CW, Hsu PT, Wang JL, et al. (2006) Efficacy of intra-articular hyaluronic acid in patients with osteoarthritis of the ankle: a prospective study. Osteoarthritis Cartilage 14(9):867-74.

75. Filkova M, Senolt L, Braun M, Hulejova H, Pavelkova A, Sleglova O, et al. (2009) Serum hyaluronic acid as a potential marker with a predictive value for further radiographic progression of hand osteoarthritis. Osteoarthritis Cartilage.

76. Schumacher HR, Meador R, Sieck M, Mohammed Y (2004) Pilot Investigation of Hyaluronate Injections for First Metacarpal-Carpal (MC-C) Osteoarthritis. J Clin Rheumatol 10(2):59-62.

77. Stahl S, Karsh-Zafrir I, Ratzon N, Rosenberg N (2005) Comparison of intraarticular injection of depot corticosteroid and hyaluronic acid for treatment of degenerative trapeziometacarpal joints. J Clin Rheumatol 11(6):299-302.

78. Bahadir C, Onal B, Dayan VY, Gurer N (2009) Comparison of therapeutic effects of sodium hyaluronate and corticosteroid injections on trapeziometacarpal joint osteoarthritis. Clin Rheumatol 28(5):529-33.

79. Fuchs S, Monikes R, Wohlmeiner A, Heyse T (2006) Intra-articular hyaluronic acid compared with corticoid injections for the treatment of rhizarthrosis. Osteoarthritis Cartilage 14(1):82-8.

80. van Brakel RW, Eygendaal D (2006) Intra-articular injection of hyaluronic acid is not effective for the treatment of post-traumatic osteoarthritis of the elbow. Arthroscopy 22(11):1199-203.

81. Bjornland T, Gjaerum AA, Moystad A (2007) Osteoarthritis of the 
temporomandibular joint: an evaluation of the effects and complications of corticosteroid injection compared with injection with sodium hyaluronate. J Oral Rehabil 34(8):583-9.

82. Arrich J, Piribauer F, Mad P, Schmid D, Klaushofer K, Mullner M (2005) Intra-articular hyaluronic acid for the treatment of osteoarthritis of the knee: systematic review and meta-analysis. CMAJ 172(8):1039-43.

83. Divine JG, Zazulak BT, Hewett TE (2007) Viscosupplementation for knee osteoarthritis: a systematic review. Clin Orthop Relat Res 455:113-22.

84. Wang CT, Lin J, Chang CJ, Lin YT, Hou SM (2004) Therapeutic effects of hyaluronic acid on osteoarthritis of the knee. A meta-analysis of randomized controlled trials. J Bone Joint Surg Am 86-A(3):538-45.

85. Modawal A, Ferrer M, Choi HK, Castle JA (2005) Hyaluronic acid injections relieve knee pain. J Fam Pract 54(9):758-67.

86. Bellamy N (2006) Hyaluronic acid and knee osteoarthritis. J Fam Pract 55(11):967-8.

87. Salini V, De Amicis D, Abate M, Natale MA, Di Iorio A (2009) Ultrasoundguided hyaluronic acid injection in carpometacarpal osteoarthritis: short-term results. Int J Immunopathol Pharmacol 22(2):455-60.

88. Clerc D (2006) Sinovial ${ }^{\circledR}$ dans la gonarthrose: une étude en situation réelle d'utilisation chez 408 patients. Rhumatos 3((Suppl. 1)):1-4.

89. Pavelka K (2010) Efficacy evaluation of a highly purified intra-articular hyaluronic acid obtained by bacterial fermentation vs hylan G-F20 in the treatment of symptomatic knee osteoarthritis: a double-blind, controlled, randomized, parallelgroup non-inferiority study [abstract]. Osteoporos Int 21(Suppl 1):S387.

90. Wei N, Delauter SK, S JB (2002) Arthroscopic debridement and viscosupplementation: a minimally invasive treatment for symptomatic osteoarthritis involving the base of the thumb. J 8(3):125-9.

91. Lohmander LS, Dalen N, Englund G, Hamalainen M, Jensen EM, Karlsson K, et al. (1996) Intra-articular hyaluronan injections in the treatment of osteoarthritis of the knee: a randomised, double blind, placebo controlled multicentre trial. Hyaluronan Multicentre Trial Group. Ann Rheum Dis 55(7):424-31.

92. Puhl W, Bernau A, Greiling H, Kopcke W, Pforringer W, Steck KJ, et al. (1993) Intra-articular sodium hyaluronate in osteoarthritis of the knee: a multicenter, double-blind study. Osteoarthritis Cartilage 1(4):233-41.

93. Wu JJ, Shih LY, Hsu HC, Chen TH (1997) The double-blind test of sodium hyaluronate (ARTZ) on osteoarthritis knee. Zhonghua Yi Xue Za Zhi (Taipei) 59(2):99-106. 
Table 1. Preparations of intra-articular hyaluronic acid (HA) and hylan available in Europe and/or the USA

\begin{tabular}{|c|c|c|c|c|}
\hline Tradename & $\begin{array}{c}\text { Concentratio } \\
\mathrm{n}(\mathrm{mg} / \mathrm{ml})\end{array}$ & $\begin{array}{l}\text { Generic } \\
\text { name }\end{array}$ & Source (type) & $\begin{array}{c}\text { Molecular } \\
\text { weight } \\
\text { (kDa) }\end{array}$ \\
\hline Adant $^{\circledR}$ & $25 \mathrm{mg} / 2.5 \mathrm{ml}$ & $\begin{array}{l}\text { sodium } \\
\text { hyaluronate }\end{array}$ & Biofermentation & 900 \\
\hline Arthrum $^{\circledR}$ & $40 \mathrm{mg} / 2 \mathrm{ml}$ & $\begin{array}{l}\text { sodium } \\
\text { hyaluronate }\end{array}$ & Biofermentation & 2400 \\
\hline Artz $^{\circledR} /$ Supartz $^{\circledR}$ & $25 \mathrm{mg} / 2.5 \mathrm{ml}$ & $\begin{array}{l}\text { sodium } \\
\text { hyaluronate }\end{array}$ & $\begin{array}{l}\text { Rooster combs } \\
\text { (avian) }\end{array}$ & $600-1200$ \\
\hline Coxarthrum $^{\circledR}$ & $75 \mathrm{mg} / 3 \mathrm{ml}$ & $\begin{array}{l}\text { sodium } \\
\text { hyaluronate }\end{array}$ & Biofermentation & 2400 \\
\hline Durolane $^{\circledR}$ & $20 \mathrm{mg} / 3 \mathrm{ml}$ & $\begin{array}{l}\text { sodium } \\
\text { hyaluronate }\end{array}$ & Biofermentation & n.a. \\
\hline Erectus $^{\circledR}$ & n.a. & n.a. & n.a. & 1100 \\
\hline Euflexxa $^{\circledR}$ & $20 \mathrm{mg} / 2 \mathrm{ml}$ & $\begin{array}{l}\text { sodium } \\
\text { hyaluronate }\end{array}$ & Biofermentation & $2400-3600$ \\
\hline Fermathron $^{\circledR}$ & $20 \mathrm{mg} / 2 \mathrm{ml}$ & $\begin{array}{l}\text { sodium } \\
\text { hyaluronate }\end{array}$ & Biofermentation & 1000 \\
\hline $\begin{array}{l}\text { Go-On }{ }^{\circledR} \\
\text { Go-On }{ }^{\circledR} \text { Mini }\end{array}$ & $\begin{array}{l}25 \mathrm{mg} / 2.5 \mathrm{ml} \\
10 \mathrm{mg} / 1 \mathrm{ml}\end{array}$ & $\begin{array}{l}\text { sodium } \\
\text { hyaluronate }\end{array}$ & Biofermentation & $800-1200$ \\
\hline Hyalart $^{\circledR}$ & $20 \mathrm{mg} / 2 \mathrm{ml}$ & $\begin{array}{l}\text { sodium } \\
\text { hyaluronate }\end{array}$ & $\begin{array}{l}\text { Rooster combs } \\
\text { (avian) }\end{array}$ & $500-730$ \\
\hline Hyalgan $^{\circledR}$ & $20 \mathrm{mg} / 2 \mathrm{ml}$ & $\begin{array}{l}\text { sodium } \\
\text { hyaluronate }\end{array}$ & $\begin{array}{l}\text { Rooster combs } \\
\text { (avian) }\end{array}$ & $500-730$ \\
\hline Hyalubrix $^{\circledR}$ & $30 \mathrm{mg} / 2 \mathrm{ml}$ & $\begin{array}{l}\text { sodium } \\
\text { hyaluronate }\end{array}$ & Biofermentation & $>1500$ \\
\hline $\begin{array}{l}\text { Intragel }^{\circledR} 0.8 \% \\
\text { Intragel }^{\circledR} 1.6 \%\end{array}$ & $\begin{array}{l}16 \mathrm{mg} / 2 \mathrm{ml} \\
32 \mathrm{mg} / 2 \mathrm{ml}\end{array}$ & $\begin{array}{l}\text { sodium } \\
\text { hyaluronate }\end{array}$ & Biofermentation & $800-1200$ \\
\hline $\begin{array}{l}\text { Jointex }^{\circledR} \\
\text { Jointex }{ }^{\circledR} \text { Starter }\end{array}$ & $\begin{array}{l}16 \mathrm{mg} / 2 \mathrm{ml} \\
32 \mathrm{mg} / 2 \mathrm{ml}\end{array}$ & $\begin{array}{l}\text { sodium } \\
\text { hyaluronate }\end{array}$ & Biofermentation & $800-1200$ \\
\hline MonoVisc $^{\circledR}$ & $20 \mathrm{mg} / \mathrm{ml}$ & $\begin{array}{l}\text { sodium } \\
\text { hyaluronate }\end{array}$ & $\begin{array}{l}\text { Biofermentation, } \\
\text { lightly cross- } \\
\text { linked }\end{array}$ & n.a. \\
\hline $\mathrm{NeoVisc}^{\circledR}$ & $20 \mathrm{mg} / 2 \mathrm{ml}$ & $\begin{array}{l}\text { sodium } \\
\text { hyaluronate }\end{array}$ & Biofermentation & 1000 \\
\hline $\begin{array}{l}\text { Orthovisc }^{\circledR} \\
\text { Orthovisc }{ }^{\circledR} \text { mini }\end{array}$ & $\begin{array}{l}30 \mathrm{mg} / 2 \mathrm{ml} \\
15 \mathrm{mg} / 1 \mathrm{ml}\end{array}$ & $\begin{array}{l}\text { high } \\
\text { molecular } \\
\text { weight } \\
\text { hyaluronan }\end{array}$ & $\begin{array}{l}\text { Biofermentation/ } \\
\text { chemical } \\
\text { modification }\end{array}$ & $\begin{array}{c}1100-2900 \\
1450\end{array}$ \\
\hline $\begin{array}{l}\text { Ostenil }^{\circledR} \\
\text { Ostenil }{ }^{\circledR} \text { mini }\end{array}$ & $\begin{array}{l}20 \mathrm{mg} / 2 \mathrm{ml} \\
10 \mathrm{mg} / \mathrm{ml}\end{array}$ & $\begin{array}{l}\text { sodium } \\
\text { hyaluronate }\end{array}$ & Biofermentation & 1200 \\
\hline
\end{tabular}




\begin{tabular}{|c|c|c|c|c|}
\hline RenehaVis $^{\circledR}$ & $\begin{array}{l}7 \mathrm{mg} / 0.7 \mathrm{ml}+ \\
15.4 \mathrm{mg} / 0.7 \mathrm{ml}\end{array}$ & $\begin{array}{l}\text { sodium } \\
\text { hyaluronate }\end{array}$ & Biofermentation & $\begin{array}{l}1000 \\
2000\end{array}$ \\
\hline $\begin{array}{l}\text { Sinovial }^{\circledR} \\
\text { Sinovial } \\
\text { Sinovial }{ }^{\circledR} \text { Morte }\end{array}$ & $\begin{array}{r}16 \mathrm{mg} / 2 \mathrm{ml} \\
8 \mathrm{mg} / 1 \mathrm{ml} \\
32 \mathrm{mg} / 2 \mathrm{ml}\end{array}$ & $\begin{array}{l}\text { sodium } \\
\text { hyaluronate }\end{array}$ & Biofermentation & $800-1200$ \\
\hline SportVis ${ }^{\circledR}$ & $12 \mathrm{mg} / 1.2 \mathrm{ml}+$ & $\begin{array}{l}\text { sodium } \\
\text { hyaluronate }\end{array}$ & Biofermentation & n.a. \\
\hline $\begin{array}{l}\text { Suplasyn }^{\circledR} \\
\text { Suplasyn }{ }^{\circledR} \text { m.d. }\end{array}$ & $\begin{array}{l}20 \mathrm{mg} / 2 \mathrm{ml} \\
7 \mathrm{mg} / 0.7 \mathrm{ml}\end{array}$ & $\begin{array}{l}\text { sodium } \\
\text { hyaluronate }\end{array}$ & Biofermentation & $500-730$ \\
\hline $\begin{array}{l}\text { Synocrom }^{\circledR} \\
\text { Synocrom }^{\circledR} \text { mini } \\
\text { Synocrom }\end{array}$ & $\begin{array}{l}20 \mathrm{mg} / 2 \mathrm{ml} \\
10 \mathrm{mg} / 1 \mathrm{ml} \\
40 \mathrm{mg} / 2 \mathrm{ml}\end{array}$ & $\begin{array}{l}\text { sodium } \\
\text { hyaluronate }\end{array}$ & Biofermentation & $\begin{array}{l}1600 \\
2100\end{array}$ \\
\hline $\begin{array}{l}\text { Synvisc }^{\circledR} \\
\text { Synvisc }^{\circledR} \text { One }\end{array}$ & $\begin{array}{l}16 \mathrm{mg} / 2 \mathrm{ml} \\
48 \mathrm{mg} / 6 \mathrm{ml}\end{array}$ & $\begin{array}{l}\text { Hylan G-F } \\
20\end{array}$ & $\begin{array}{l}\text { Rooster combs } \\
\text { (avian), cross- } \\
\text { linked }\end{array}$ & 6000 \\
\hline $\begin{array}{l}\text { Viscorneal- } \\
\text { ortho }^{\circledR}\end{array}$ & $20 \mathrm{mg} / 2 \mathrm{ml}$ & \begin{tabular}{|l} 
sodium \\
hyaluronate
\end{tabular} & $\begin{array}{l}\text { Rooster combs } \\
\text { (avian) }\end{array}$ & 6000 \\
\hline $\begin{array}{l}\text { Yaral }^{\circledR} \\
\text { Yaral }^{\circledR} \text { Mini } \\
\text { Yaral }^{\circledR} \text { Forte }\end{array}$ & $\begin{array}{r}16 \mathrm{mg} / 2 \mathrm{ml} \\
8 \mathrm{mg} / 1 \mathrm{ml} \\
32 \mathrm{mg} / 2 \mathrm{ml}\end{array}$ & $\begin{array}{l}\text { sodium } \\
\text { hyaluronate }\end{array}$ & Biofermentation & $800-1200$ \\
\hline
\end{tabular}


Table 2. Clinical trials of intra-articular (IA) injections of hyaluronic acid (HA) in patients with osteoarthritis (OA) of the knee

\begin{tabular}{ccccc}
\hline $\begin{array}{c}\text { Study } \\
\text { (design, } \\
\text { duration) }\end{array}$ & $\begin{array}{c}\text { Patients } \\
\text { (gender, } \\
\text { mean age, } \\
\text { weight) }\end{array}$ & $\begin{array}{c}\text { Intervention, number of } \\
\text { once-weekly injections } \\
(\mathrm{n})\end{array}$ & $\begin{array}{c}\text { Primary efficacy } \\
\text { assessments }\end{array}$ & Safety analysis \\
\hline
\end{tabular}

\section{HA vs PL}

\begin{tabular}{|c|c|c|}
\hline Carrabba et & $37 \mathrm{M} / 63 \mathrm{~F}$ & $\mathrm{HA}^{\mathrm{a}} 20 \mathrm{mg} / 2 \mathrm{ml} 1 \mathrm{x} \quad(\mathrm{n}=20)$ \\
\hline \multirow[t]{3}{*}{$\begin{array}{l}(\mathrm{db}, \mathrm{r}, \mathrm{pc}, \mathrm{sc}, \\
6 \mathrm{mo})\end{array}$} & $\begin{array}{l}60 \mathrm{yrs}, 72 \\
\mathrm{~kg}\end{array}$ & $\begin{array}{l}H A^{a} 20 m g / 2 m l 3 x \quad(n=20) \\
H A^{a} 20 m g / 2 m l 5 x(n=20)\end{array}$ \\
\hline & & Knee athrocentesis $(n=20)$ \\
\hline & & $P L(n=20)$ \\
\hline $\begin{array}{l}\text { Dixon et } \\
\text { al.[15] }\end{array}$ & $29 \mathrm{M} / 34 \mathrm{~F}$ & $\begin{array}{l}\mathrm{HA}^{\mathrm{a}} 20 \mathrm{mg} / 2 \mathrm{ml} \text { up to } 11 \\
\text { injections/23 weeks }(\mathrm{n}=33)\end{array}$ \\
\hline $\begin{array}{l}\text { (db, r, pc, } 23 \\
\text { wks) }\end{array}$ & $\begin{array}{l}69(43-85) \\
\text { yrs, } 75 \\
(42-105) \\
\mathrm{kg}\end{array}$ & $\begin{array}{l}\mathrm{PL}(\mathrm{HA} 0.25 \mathrm{mg} / 2.5 \mathrm{ml}) \\
\text { up to } 11 \text { injections } / 23 \\
\text { weeks }(\mathrm{n}=33)\end{array}$ \\
\hline
\end{tabular}

$\begin{array}{lll}\begin{array}{l}\text { Dougados et } \\ \text { al. [41] }\end{array} & 32 \mathrm{M} / 78 \mathrm{~F} & \mathrm{HA}^{\mathrm{a}} 20 \mathrm{mg} / 2 \mathrm{ml} 4 \mathrm{x}(\mathrm{n}=55) \\ & 68 \mathrm{yrs}, 70 & \mathrm{PL} 4 \mathrm{x}(\mathrm{n}=55) \\ \begin{array}{ll}(\mathrm{db}, \mathrm{r}, \mathrm{pc}, \mathrm{mc}, & \mathrm{kg} \\ 1 \mathrm{yr})\end{array}\end{array}$

$\begin{array}{lll}\begin{array}{l}\text { Listrat et } \\ \text { al.[42] }\end{array} & 13 \mathrm{M} / 26 \mathrm{~F} & \begin{array}{l}\mathrm{HA}^{\mathrm{a}} 20 \mathrm{mg} / 2 \mathrm{ml} 3 \text { cycles of } \\ 3 \times / 3 \mathrm{mo}=9 \text { in total }(\mathrm{n}=20)\end{array} \\ & 62 \mathrm{yrs} & \\ (\mathrm{r}, \mathrm{c}, 1 \mathrm{yr}) & & \text { Control }(\mathrm{n}=19)\end{array}$

Significant reductions in joint pain ${ }^{\mathrm{b}}$ at rest vs $\mathrm{PL}$ from week 5-23 and for pain ${ }^{b}$ on movement at wk 5 ( $p<0.05$ for both); no marked improvements in ADLs as only one joint treated in pts with polyarticular disease

At wk 7, improvements from baseline in pain ${ }^{b}$ after exercise (but not at rest) and functional impairment (Lequesne's index) were significantly greater with $\mathrm{HA}$ vs $\mathrm{PL}$ ( $p=0.03$ for both); at 52 weeks, significant improvements in functional index were maintained $(p<0.05)$

Pain $^{\mathrm{b}}$ and functional impairment improved in both groups (NS); athroscopic parameters showed significantly less structural deterioration with HA vs control; QoL assessment significantly better with $\mathrm{HA}$ vs control at $1 \mathrm{yr}(\mathrm{p} \leq 0.05)$

$\begin{array}{lll}\begin{array}{l}\text { Lohmander et } \\ \text { al.[91] }\end{array} & 106 \mathrm{M} / 134 \mathrm{~F} & \begin{array}{l}\mathrm{HA}^{\mathrm{c}} 25 \mathrm{mg} / 2.5 \mathrm{ml}(1 \%) 5 \mathrm{x} \\ (\mathrm{n}=96)\end{array} \\ \begin{array}{lll}\text { (r, db, pc, mc, } \\ 5 \text { wks })\end{array} & \begin{array}{l}58 \mathrm{yrs}, 79 \\ \mathrm{Mg}\end{array} & \mathrm{PL}(\mathrm{n}=93)\end{array}$

Lequesne algofunctional index, pain ${ }^{\mathrm{b}}$, range of motion $^{b}$, activity level ${ }^{b}$ and total knee function ${ }^{b}$ were improved from baseline with both $\mathrm{HA}$ and $\mathrm{PL}$; stratification by age ( $>60$ years) and baseline
One transient local AE (pain postinjection) in each group except $\mathrm{PL}$; no relevant changes in laboratory parameters

Well tolerated, 1 case of haemarthrosis in HA group; no clinically significant changes in laboratory parameters

Minor and transient AEs, not considered treatment-related; no clinically significant changes in laboratory parameters

Not done

No serious AEs; severity of injection site swelling greater with $\mathrm{HA}$ than PL $(p=0.041)$; AEs led to $5 \mathrm{PL}$ and $2 \mathrm{HA}$ recipients 


\begin{tabular}{|c|c|c|c|}
\hline & & & $\begin{array}{l}\text { algofunctional index }(>10) \\
\text { showed significantly } \\
\text { greater improvements } \\
\text { with HA vs PL }(p<0.05)\end{array}$ \\
\hline Puhl et al.[92] & & $\begin{array}{l}\mathrm{HA}^{\mathrm{d}} 25 \mathrm{mg} / 2.5 \mathrm{ml} 5 \mathrm{x} \\
(\mathrm{n}=95)\end{array}$ & \multirow{2}{*}{$\begin{array}{l}\text { Compared with control, } \\
\text { progressive and } \\
\text { significant reduction in } \\
\text { mean Lequesne Index of } \\
\text { the severity of the knee } \\
\text { joint from wk } 3-14 \\
(p<0.025)\end{array}$} \\
\hline $\begin{array}{l}\text { (r,db,pg,mc, } 14 \\
\text { wks) }\end{array}$ & $\begin{array}{l}61 \text { yrs, } 75 \\
\mathrm{~kg}\end{array}$ & $\begin{array}{l}\text { Control (HA } 0.25 \mathrm{mg} / 2.5 \\
\mathrm{ml}) 5 x(\mathrm{n}=100)\end{array}$ & \\
\hline Wu et al.[93] & $83 \mathrm{M} / 33 \mathrm{~F}$ & $\mathrm{HA}^{\mathrm{d}} 2.5 \mathrm{ml}(1 \%) 5 \mathrm{x}(\mathrm{n}=62)$ & \multirow{2}{*}{$\begin{array}{l}\text { Mean values for clinical } \\
\text { symptoms and } A D L \text { were } \\
\text { markedly improved with } \\
\text { HA vs PL from wk } 5 \text {; } \\
\text { significant improvements } \\
\text { with HA vs } P L(p<0.05) \text {, } \\
\text { especially for relief of } \\
\text { motion pain and knee } \\
\text { movement, with a peak at } \\
6 \text { wks, improvements } \\
\text { sustained up to } 3 \text { mo }\end{array}$} \\
\hline $\begin{array}{l}(r, d b, p c, m c \\
6 m o)\end{array}$ & $69 \mathrm{yrs}$, & $P L(n=54)$ & \\
\hline
\end{tabular}

Non-comparative trials with HA

$\begin{array}{lll}\begin{array}{l}\text { Novaes et } \\ \text { al.[43] }\end{array} & 69 \mathrm{M} / 296 \mathrm{~F} & \begin{array}{l}\mathrm{HA}^{\mathrm{e}} 25 \mathrm{mg} / 2.5 \mathrm{ml} 5 \mathrm{x} \\ (\mathrm{n}=296)\end{array} \\ \begin{array}{ll}\text { (ol, mc, 5 wks) } & 65 \mathrm{yrs}\end{array} & \end{array}$

$\begin{array}{lll}\text { Petrella[44] } & 188 \mathrm{M} / 349 & \mathrm{HA}^{\dagger}(10 \mathrm{mg} / \mathrm{ml} / 2 \mathrm{ml}) 3 \mathrm{x} \\ & \mathrm{F} & (\mathrm{n}=537) \\ \begin{array}{ll}\text { (prospective, } \\ \text { naturalistic, }\end{array} & \begin{array}{l}68 \mathrm{yrs}, \mathrm{BMl} \\ 6.7 \mathrm{yrs})\end{array} & =27 \mathrm{~kg} / \mathrm{m}^{2}\end{array}$

\section{HA vs active treatment}

$\begin{array}{lll}\begin{array}{l}\text { Altman et } \\ \text { al.[45] }\end{array} & \text { 143M/190F } & \mathrm{HA}^{\mathrm{a}} 5 \times 20 \mathrm{mg} / 2 \mathrm{ml}(\mathrm{n}=105) \\ & \mathrm{PL}(\mathrm{n}=115) \\ \text { (r, pc, 26 wks) } & \begin{array}{l}64(40-90) \\ \text { yrs, 89 Kg }\end{array} & \begin{array}{l}\text { Naproxen 500mg bid PO } \\ (\mathrm{n}=113)\end{array}\end{array}$

Pain ${ }^{b}$ during a 50 foot walk was less with $\mathrm{HA}$ vs $\mathrm{PL}$ from week 1 through 26 ( $p<0.05$ at wks 4, 5, $12,21)$ and maximally less at wk $26(p=0.004)$

Pain was also less with HA vs naproxen from wk 4-26

withdrawing prior to $5^{\text {th }}$ injection

Tolerability was $\mathrm{good} /$ very good in both groups $(96 \%$ for both); $4 \mathrm{HA}$ and 5 control pts had a transient local $A E$ (pain postinjection); no between-group difference in laboratory parameters

No side effects reported over 6 mo follow-up

AEs in $3 \%$ of administrations included synovitis $(n=5)$, pruritus (1), eczema (1), pain at injection site (3) and tendonitis (1)

\section{Few minor local} AEs (pain and swelling) significant at visit 2, 3 and $4(81 \% ; p<0.001)$ of the $1^{\text {st }}$ series of injections, and at visit 6,7 and 8 $(87 \% ; p<0.001)$ of second series 6 mo after the $1^{\text {st }}$

Incidence of injection site pain greater with HA vs PL or naproxen (23\% vs $13 \%$ and $9 \% ; p<0.001)$ that lead to study withdrawal from each group $(6,1$, and 1); more Gl AEs with naproxen vs $\mathrm{HA}$ and $\mathrm{PL}$ 


\begin{tabular}{|c|c|c|c|c|}
\hline & & & & $\begin{array}{l}(41 \% \text { vs } 29 \% \text { and } \\
36 \% ; p=0.087) \\
\text { leading to } 14,4 \\
\text { and } 4 \text { withdrawals }\end{array}$ \\
\hline Jones et & $24 \mathrm{M} / 39 \mathrm{~F}$ & $H A^{a} 20 m g 5 x(n=32)$ & \multirow{2}{*}{$\begin{array}{l}\text { Trend for less pain }{ }^{\mathrm{b}} \text { on } \\
\text { activity, rest and at night } \\
\text { in the HA than the TH } \\
\text { group from wk } 4-29\end{array}$} & \multirow{2}{*}{$\begin{array}{l}\text { High dropout } \\
\text { rate, } 19 \text { in the } \mathrm{HA} \\
\text { and } 23 \text { in the } \mathrm{TH} \\
\text { group }\end{array}$} \\
\hline$(\mathrm{db}, \mathrm{r}, 6 \mathrm{mo})$ & $71 \mathrm{yrs}$ & $\begin{array}{l}\text { Triamcinolone } \\
\text { hexacetonide }(T H) 20 \mathrm{mg} \\
\mathrm{I} A+4 x \mathrm{PL}(\mathrm{n}=31)\end{array}$ & & \\
\hline
\end{tabular}

\footnotetext{
${ }^{a}$ Hyalgan ${ }^{\circledR}$, Fidia S.p.A., Italy

${ }^{\mathrm{b}}$ Assessed using $100 \mathrm{~mm}$ Visual Analogue Scales (VAS)

${ }^{c}$ Artzal®, Astra Läkemedel, Sweden

d ARTZ®, Seikagaku Co., Tokyo, Japan

${ }^{\mathrm{e}}$ Adant ${ }^{\circledR}$, Meiji Seika Kaisha, Japan

${ }^{\dagger}$ Suplasyn®, Bioniche Life Sciences, Switzerland
}

$\mathrm{ADL}=$ activities of daily living; $\mathrm{db}=$ double-blind; NSAID = non-steroidal anti-inflammatory drug; $\mathrm{mc}=$ multi-centre; $\mathrm{mo}=$ months $;$ ol = open-label; pts = patients; $p c=$ placebo-controlled; $p g=$ parallel-group; $\mathrm{PL}=$ placebo; $\mathrm{PO}=$ per os; $\mathrm{r}=$ randomised; $\mathrm{sc}=$ single-centre $; \mathrm{wk}=$ week $; \mathrm{yr}=$ year. 
Table 3. Clinical trials of intra-articular (IA) injections of hylan in patients with osteoarthritis (OA) of the knee

\begin{tabular}{|c|c|c|c|c|}
\hline $\begin{array}{l}\text { Study (design, } \\
\text { duration) }\end{array}$ & $\begin{array}{c}\text { Patients } \\
\text { (gender, } \\
\text { mean age, } \\
\text { weight) }\end{array}$ & $\begin{array}{c}\text { Intervention, } \\
\text { number of once- } \\
\text { weekly injections (n) }\end{array}$ & $\begin{array}{l}\text { Primary efficacy } \\
\text { assessments }\end{array}$ & Safety analysis \\
\hline
\end{tabular}

Hylan vs PL

\begin{tabular}{|c|c|c|c|}
\hline \multirow{3}{*}{$\begin{array}{l}\text { Wobig et al.[47] } \\
\text { (r, db, mc, } 12 \\
\text { wks) }\end{array}$} & $38 \mathrm{M} / 72 \mathrm{~F}$ & $\begin{array}{l}\text { Hylan G-F } 20^{\mathrm{a}} 2.0 \mathrm{ml} \\
(0.8 \%) 3 x(\mathrm{n}=52)\end{array}$ & \multirow{3}{*}{$\begin{array}{l}\text { Pain }{ }^{\mathrm{b}} \text { scores during weight } \\
\text { bearing ( wk } 3-26) \text {, at night } \\
\text { rest, and during the most } \\
\text { painful movement of knee, in } \\
\text { addition to treatment success } \\
\text { at } 12 \text { wks, were all better with } \\
\text { hylan vs control ( } p<0.01 \text { for } \\
\text { all) }\end{array}$} \\
\hline & $\begin{array}{l}62 \mathrm{yrs}, 76 \\
\mathrm{~kg}\end{array}$ & Saline $(n=54)$ & \\
\hline & & $\begin{array}{l}\text { Hylan G-F } 20^{a}+ \\
\text { Saline }(n=4)\end{array}$ & \\
\hline
\end{tabular}

3 hylan recipients reported systemic reactions - itching, cramps, and haemorrhoids

\section{Hylan vs Comparator}

\begin{tabular}{|c|c|c|}
\hline Adams et al.[48] & $36 \mathrm{M} / 66 \mathrm{~F}$ & $\begin{array}{l}\text { Hylan G-F } 20^{\mathrm{a}} 2.0 \mathrm{ml} \\
3 \mathrm{x}(\mathrm{n}=31)\end{array}$ \\
\hline $\begin{array}{l}\text { (r, mc, pg, } 26 \\
\text { wks) }\end{array}$ & $\begin{array}{l}61(35-76) \\
\text { yrs, } 72 \mathrm{~kg}\end{array}$ & NSAID $(n=34)$ \\
\hline & & $\begin{array}{l}\text { NSAID + Hylan G-F } \\
20^{\mathrm{a}} 2.0 \mathrm{ml} 3 x(\mathrm{n}=37)\end{array}$ \\
\hline
\end{tabular}

Pain ${ }^{b}$ on motion with weightbearing, at rest, at night, restriction of activity and overall assessment of arthritic pain were all significantly improved vs baseline at wk 12 in all groups $(p<0.01)$; at 26 wks, improvements in the the hylan and the hylan + NSAID group were significantly better in some, and every evaluation, respectively, vs NSAID

\begin{tabular}{|c|c|c|}
\hline $\begin{array}{l}\text { Dickson et } \\
\text { al.[49] }\end{array}$ & $\begin{array}{l}73 \mathrm{M} / 92 \mathrm{~F} \\
64(35-81)\end{array}$ & $\begin{array}{l}\text { Hylan G-F } 20^{a} \\
(20 \mathrm{mg} / 2 \mathrm{ml}) 3 x \\
(\mathrm{n}=53)\end{array}$ \\
\hline \multirow[t]{2}{*}{$\begin{array}{l}\text { (db, r, pc, pg, } \\
12 \text { wks) }\end{array}$} & yrs & $\begin{array}{l}\text { Diclofenac } 100 \\
\text { mg/day }+3 x \\
\text { athrocentesls }(n=55)\end{array}$ \\
\hline & & Control: $(n=57)$ \\
\hline $\begin{array}{l}\text { Leopold et } \\
\text { al.[50] }\end{array}$ & $37 \mathrm{M} / 43 \mathrm{~F}$ & $\begin{array}{l}\text { Hylan G-F } 20^{\mathrm{a}} 2.0 \mathrm{ml} \\
(0.8 \%) 3 x(\mathrm{n}=38)\end{array}$ \\
\hline (r, $6 \mathrm{mo})$ & $\begin{array}{l}65 \text { yrs, } 86 \\
\mathrm{~kg}\end{array}$ & $\begin{array}{l}\text { Betamethasone } \\
\text { sodium phosphate- } \\
\text { betamethasone } \\
\text { acetate } 2 \mathrm{ml}(n=42)\end{array}$ \\
\hline
\end{tabular}

Improvements from baseline in the WOMAC A score were significant with Hylan G-F 20 vs control (33 vs $24 ; p=0.04$ ) and diclofenac (33 vs 23 ; $\mathrm{p}=0.03$ ), but not for diclofenac vs control $(p=0.84)$

WOMAC scores improved from baseline in both groups $(p<0.01)$; VAS scores improved from baseline with Hylan G-F 20-but not with corticosteroid $(p<0.01)$; no significant between-group difference on any scale
3 pts reported transient local reactions ( 2 were pain with warmth and effusion within 24-hrs of injection) in the hylan group resulting in one study withdrawal

Significantly more systemic $(48 \%$ vs $22 \%$ and $11 \%$ ) and $\mathrm{Gl}$ adverse events (38\% vs $12 \%$ and $9 \%$ with diclofenac vs Hylan G-F 20 and control $(p<0.01$ for both)

One pt in the Hylan G-F 20 group withdrew due to an acute local reaction within 24-hrs of an injection

\footnotetext{
${ }^{a}$ Synvisc ${ }^{\circledR}$, Genzyme Biosurgery, US

${ }^{\mathrm{b}}$ Assessed using $100 \mathrm{~mm}$ Visual Analogue Scales (VAS)

$\mathrm{db}=$ double-blind; $\mathrm{mo}=$ month; NSAID = non-steroidal anti-inflammatory drug; $\mathrm{mc}=$ multi-centre; $\mathrm{pc}=$ placebo-controlled; $p g$ = parallel-group; $\mathrm{PL}=$ placebo; $\mathrm{pt}=$ patient; $r$ = randomised; $w \mathrm{k}=$ week; $\mathrm{yr}=$ year.
} 
Table 4. Clinical trials of intra-articular (IA) injections of hyaluronic acid (HA) vs hylan in patients with osteoarthritis (OA) of the knee

\begin{tabular}{|c|c|c|c|c|}
\hline $\begin{array}{l}\text { Study (design, } \\
\text { duration) }\end{array}$ & $\begin{array}{c}\text { Patients } \\
\text { (gender, } \\
\text { mean age, } \\
\text { weight) }\end{array}$ & $\begin{array}{l}\text { Intervention, number } \\
\text { of once-weekly } \\
\text { injections (n) }\end{array}$ & $\begin{array}{l}\text { Primary efficacy } \\
\text { assessments }\end{array}$ & Safety analysis \\
\hline \multicolumn{5}{|l|}{ HA vs Hylan } \\
\hline $\begin{array}{l}\text { Karatosun et } \\
\text { al.[51] } \\
(\mathrm{r}, \mathrm{db}, 1 \mathrm{yr})\end{array}$ & $\begin{array}{l}17 \mathrm{M} / 75 \mathrm{~F} \\
61 \mathrm{yrs}, \mathrm{BMI} \\
30 \mathrm{~kg} / \mathrm{m}^{2}\end{array}$ & $\begin{array}{l}\mathrm{HA}^{\mathrm{a}} 3 \mathrm{x}(\mathrm{n}=46) \\
\text { Hylan G-F } 20^{\mathrm{b}} 2.0 \mathrm{ml} \\
(0.8 \%) 3 \mathrm{x}(\mathrm{n}=46)\end{array}$ & $\begin{array}{l}\text { At } 1 \text { yr, mean } \\
\text { improvement in total } \\
\text { Hospital for Special } \\
\text { Surgery knee score was } \\
\text { significantly greater than } \\
\text { baseline with HA and } \\
\text { hylan, both } p<0.01\end{array}$ & $\begin{array}{l}\text { No reported } \\
\text { injection-related } \\
\text { AEs }\end{array}$ \\
\hline $\begin{array}{l}\text { Karlsson et } \\
\text { al.[52] } \\
(r, \mathrm{db}, \mathrm{pc}, 1 \mathrm{yr})\end{array}$ & $\begin{array}{l}97 \mathrm{M} / 143 \mathrm{~F} \\
71 \mathrm{yrs} \\
80 \mathrm{~kg}\end{array}$ & $\begin{array}{l}\mathrm{HA}^{\mathrm{c}} 2.5 \mathrm{ml}(1 \%) 3 \mathrm{x} \\
(\mathrm{n}=72) \\
\text { Hylan G-F } 20^{\mathrm{b}} 2.0 \mathrm{ml} \\
(0.8 \%) 3 x(\mathrm{n}=71) \\
\text { PL 3x }(\mathrm{n}=71)\end{array}$ & $\begin{array}{l}\text { Weight-bearing pain } \\
\text { during the first } 26 \text { wks } \\
\text { was similar with each } \\
\text { treatment and PL; neither } \\
\text { treatment alone showed a } \\
\text { significantly longer } \\
\text { duration of clinical benefit } \\
\text { vs PL over } 0-52 \text { wks but } \\
\text { when data from these } \\
\text { groups was pooled, } \\
\text { significance vs PL was } \\
\text { shown }(p=0.047)\end{array}$ & $\begin{array}{l}\text { No treatment- } \\
\text { related AEs }\end{array}$ \\
\hline $\begin{array}{l}\text { Wobig et al.[29] } \\
\text { (db, r, mc, } 12 \\
\text { wks) }\end{array}$ & $\begin{array}{l}34 \mathrm{M} / 36 \mathrm{~F} \\
60(22-88) \\
\mathrm{yrs}\end{array}$ & $\begin{array}{l}\text { Hylan G-F } 20^{\mathrm{b}} 2.0 \mathrm{ml} \\
(0.8 \%) 3 x(\mathrm{n}=38) \\
\text { LMW HA }^{\mathrm{e}}(1 \%) 2.0 \mathrm{ml} \\
3 x(\mathrm{n}=32)\end{array}$ & $\begin{array}{l}\text { Significant improvements } \\
\text { in paind on weight- } \\
\text { bearing, most painful knee } \\
\text { movement, and overall } \\
\text { treatment response with } \\
\text { Hylan G-F } 20 \text { vs LMW HA } \\
\text { at wk } 12(p<0.05)\end{array}$ & $\begin{array}{l}\text { No systemic AEs, } \\
\text { more (NS) local } \\
\text { AEs (pain/swelling) } \\
\text { with Hylan G-F } 20 \\
\text { vs LMW HA (1.8\% } \\
\text { vs } 0.9 \%)\end{array}$ \\
\hline
\end{tabular}

${ }^{a}$ Orthovisc $\circledast$, Anika, Biomeks, Turkey

${ }^{\text {b }}$ Synvisc ${ }^{\circledR}$, Genzyme Biosurgery, USA

${ }^{c}$ Artzal® ${ }^{\circledR}$, Astra Läkemedel, Sweden

${ }^{\mathrm{d}}$ Assessed using $100 \mathrm{~mm}$ visual analogue scales (VAS)

e Artzal®, Seikagaku, Kogyo Co. Ltd, Tokyo, Japan

$\mathrm{AE}=$ adverse event; $\mathrm{db}=$ double-blind; LMW HA = Lower -molecular-weight hyaluronan; $\mathrm{mc}=$ multicentre; $\mathrm{pc}=$ placebo-controlled; $\mathrm{PL}=$ placebo; $r$ = randomised; $w \mathrm{k}=$ week; $y r$ = year. 
Table 5. Pain (VAS score), joint mobility and hand strength in 20 patients with rhizarthrosis (grade I-III) before (baseline) and 3 months after the injection of Sinovial ${ }^{\circledR}$ Mini $0.8 \%(8 \mathrm{mg} / 1 \mathrm{ml})$ in ultrasound-guided infiltration (Dr Callegari, unpublished observation)

\begin{tabular}{|l|c|c|}
\hline Parameter & Baseline & 3 months \\
\hline VAS score & 68.1 & 25.4 \\
\hline Joint mobility & & \\
Radial abduction & $12.3^{\circ}$ & $65.3^{\circ}$ \\
Palmar abduction & $10.8^{\circ}$ & $54.5^{\circ}$ \\
Kapandji opposition & $4.0^{\circ}$ & $7.3^{\circ}$ \\
\hline Hand strength & & \\
\hline Grip strength (Kg) & 16.4 & 25.6 \\
Lateral pinch (Kg) & 5.7 & 11.8 \\
Tip pinch (Kg) & 2.7 & 6.1 \\
\hline
\end{tabular}


Table 6. Pain (VAS score), over a 12-month period, in 20 patients with rhizarthrosis (grade I-III) treated with a single injection of Sinovial ${ }^{\circledR}$ Mini $0.8 \%(8 \mathrm{mg} / 1 \mathrm{ml})$ in ultrasound-guided infiltration and receiving (a) maintenance Sinovial ${ }^{\circledR}$ injections 4 and 8 months after the first administration (baseline); (b) maintenance injection only 8 months after baseline; or (c) no maintenance injection ( $\mathrm{n}=10$ in each group) (Dr Callegari, unpublished observation)

\begin{tabular}{|l|c|c|c|c|}
\hline \multicolumn{1}{|c|}{$\begin{array}{c}\text { Maintenance } \\
\text { treatment }\end{array}$} & Baseline & 3 months & $\mathbf{6}$ months & $\mathbf{1 2}$ months \\
\hline $\begin{array}{l}4 \text { and 8 months } \\
\text { after baseline }\end{array}$ & 67.8 & 25.2 & 25.1 & 25.6 \\
\hline $\begin{array}{l}8 \text { months after } \\
\text { baseline }\end{array}$ & 68.1 & 25.4 & 45.1 & 35.5 \\
\hline No & 67.9 & 25.3 & 44.9 & 62.3 \\
\hline
\end{tabular}


Fig. 1 Efficacy of 5 once-weekly intra-articular injections of Sinovial ${ }^{\circledR}$ on selfadministered WOMAC OA Index Questionnaire in a 24-week, open-label study in 63 patients with osteoarthritis of the knee (mean \pm SEM, per protocol population[24]

<<Permission obtained: reproduced from Fig 2/pg 1731 from Theiler and Bruhlmann 2005[24]

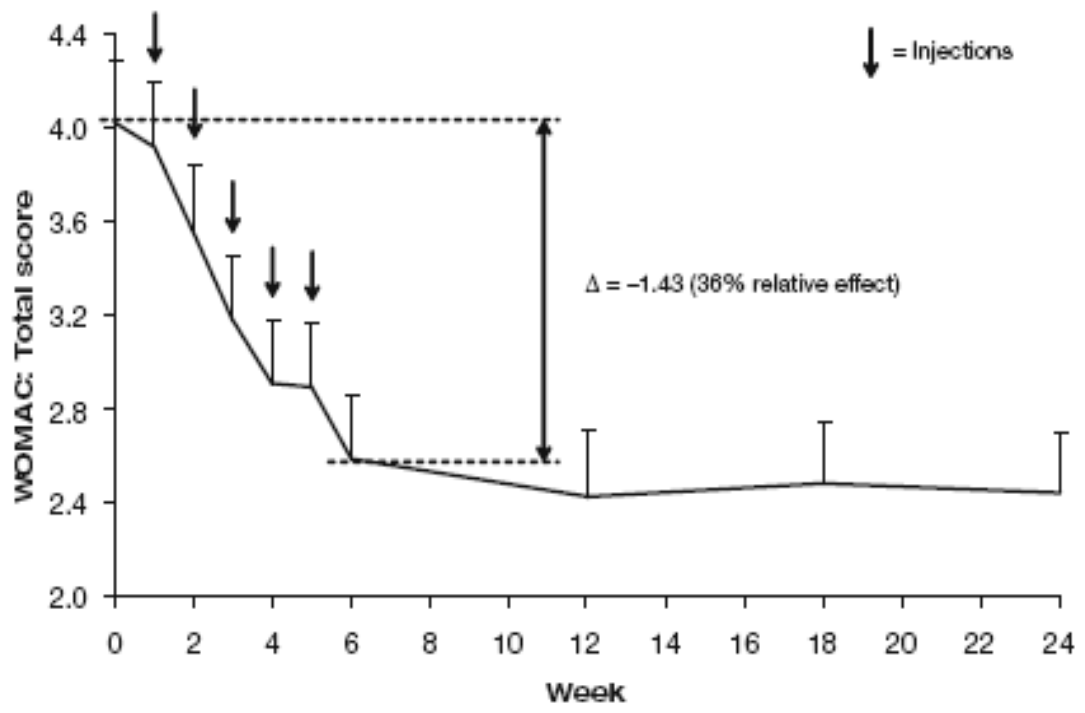


Fig. 2 Efficacy of 5 weekly intra-articular injections of Sinovial® on Lequesne's Algo-Functional Index in a 7-week, observational study in 40 patients with osteoarthritis of the knee[12]

$<<$ Permission obtained: reproduced from Fig.2/pg 70 Castellacci and Polieri 2004[12]

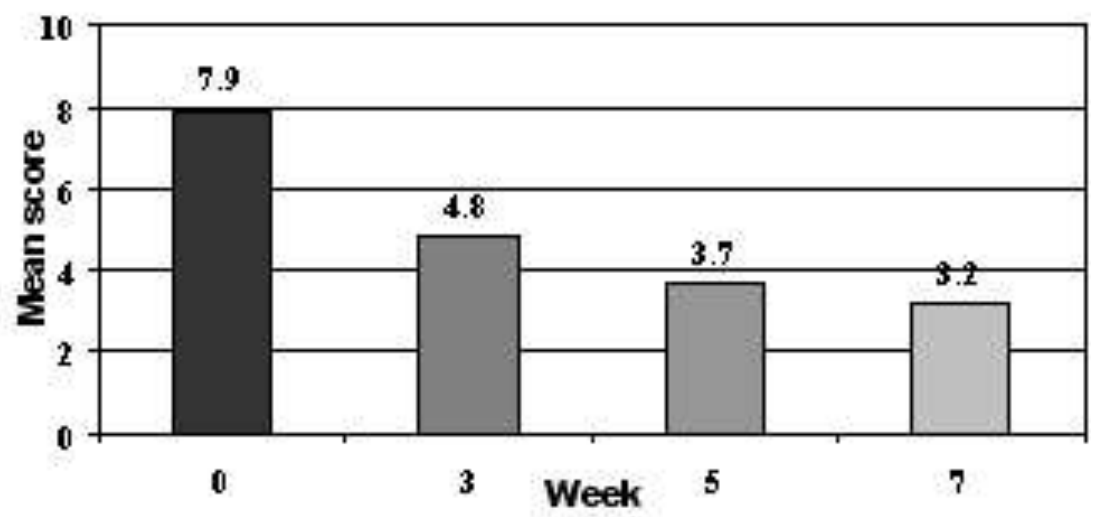


Fig. 3 Mean of WOMAC pain score from baseline to 6 months(data on file, IBSA)

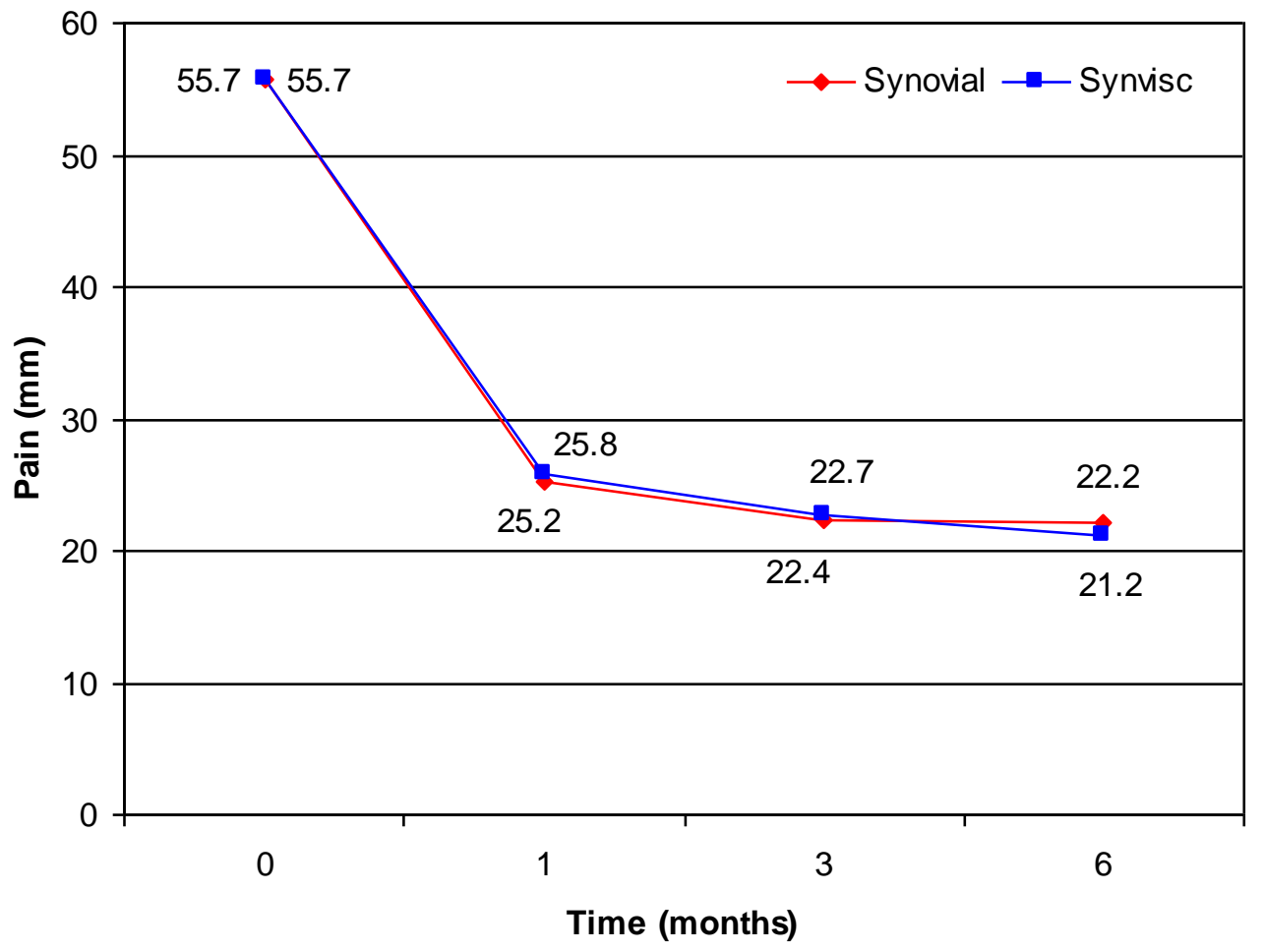

